\title{
The Railway Age in the Carpathian Forests: A Study of Romania
}

\section{Muica, N, Turnock, D.*}

\begin{abstract}
Commercial wood exploitation has been a major industry in the Carpathians since the late 19th century but its spatial progress has been influenced not only by the distribution of species (particularly fir and spruce that were highly valued in the early years) but by the possibilities for efficient transport. Initial use of the rivers gradually gave way to rail transport, including not only the main lines but many purpose-built narrow-gauge branches connecting sawmills with their catchment areas. With particular reference to Romania, the paper examines the growth of forest railways to their maximum extent in the 1950s, including some continued use of the rivers as well as specially-built inclines and funiculars to reach the more inaccessible areas. Although road transport has taken over increasingly over the last half century, the forest railway still has some commercial viability for the timber business quite apart from niche tourism linked with industrial heritage.
\end{abstract}

Key words Carpathians, forests, narrowgauge, railways, roads, Romania, wood processing
* Nicolae Muica, Geography Institute, Str. Dimitrie Racovita 12, 70307 Bucuresti 20, Romania

** David Turnock, Geography Department, The University, Leicester LE1 7RH, UK
$\mathrm{T}$ his paper examines the changing geography of wood exploitation in the L Carpathians: a heavily forested region where commercial pressures spread from northwest to southeast as the rail network widened access to Central European markets and the abolition of feudalism eliminated customary rights in favour of private ownership (Plate 1). The revaluation of woodlands brought an end to inexorable clearances by 'Wallachian' pastoralists over several centuries had substantially lowered the timberline substantially in many areas. A new generation of factories was created on the edge of the forests in the early part of the 19th century in the northeast: for example the Harmanec paperworks was opened by F.S.Leicht on the edge of Banska Bystrica in 1829 but it was massively expanded by the Huttner family during 1892-5 when railway access enabled 600 wagonloads each year to be despatched from the factory's three papermaking machines. At this time railways were penetrating the eastern Carpathians and Hungarian capitalists were moving across the border into Romania. Moreover, Romanian legislation in 1901 gave a boost to wood processing and the number of sawmills doubled from 45 in 1900 to over 90 in 1910; exceeding the annual timber increment. This paper examines the local transport implica-

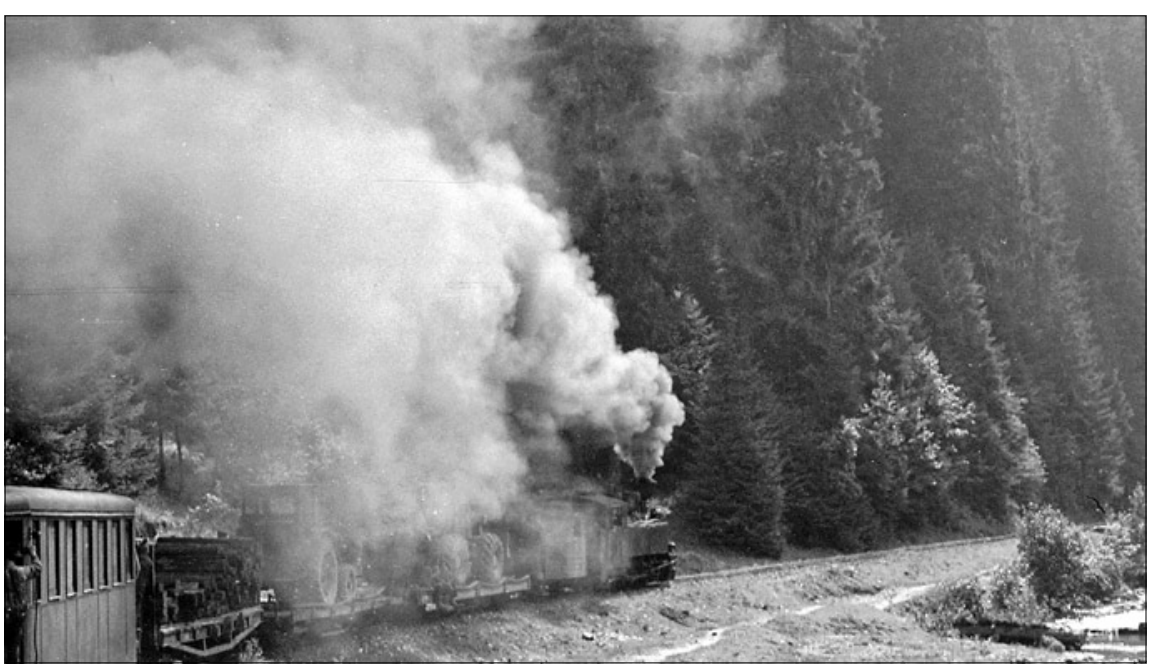

Plate 1 The Carpathian forest: a forest railway train climbing the Vasar valley in Maramures (1981). ${ }^{1}$ gare de apa') worked by peasant commu- tions with particular reference to industrial railway building in Romania. The study deals with the country's present territory and uses Romanian names for the sake of simplicity despite the history of Hungarian administration in Transylvania before 1918 and the continuing Hungarian majority in some of the areas investigated, especially Covasna and Comandau (Figure 1). Many details of the history are still obscure and some outstanding problems will be alluded to.

\section{The Pre-war Era}

Scattered water-powered sawmills ('joanities from the $17^{\text {th }}$ century were being joined by the steam-powered installations of the capitalists producing sawn timber ('cherestea') for export: also by woodusing industries concerned with furniture (for which some small towns like Pancota enjoyed a high reputation) and papermills such as those of Letea (Bacau) and Piatra Neamt in Moldavia, Busteni in Wallachia and Petresti and Prundul Bargaului in Transylvania. Forestry codes were drawn up but they were only weakly enforced on the margins of European capitalism so that sustainable yield forestry in the European core contrasted with clear-felling on the periphery wherever access to the valuable spruce-fir forests could be secured. The sustainable option of felling small parcels in succession and leaving each to regenerate was often ignored in favour of rapid clearance of a large concession, although this caused considerable erosion and prevented long term use of the transport infrastructure. Although the Romanian state became a large landowner after the secularisation of monastic lands in 1863 and organised a forest service (with a 'Cod Silvic' enacted in 1881) woodland was often sold cheaply because the state lacked the means to invest in its own transport 


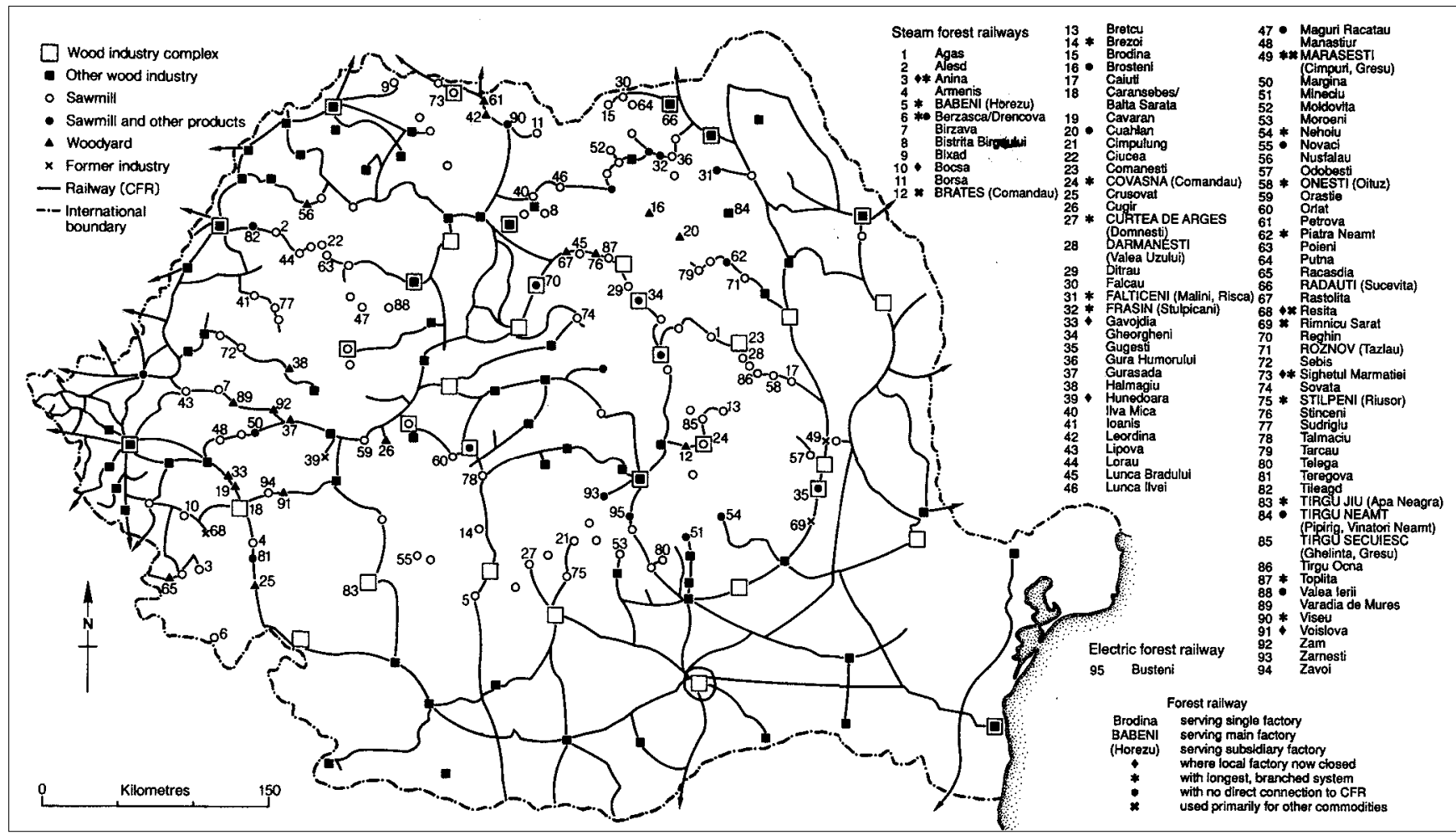

Figure 1 Forest railway systems in the Romanian Carpathians

systems. The rivers were often very useful for transporting raw timber.

Although there might be rapids in the upper reaches (the Vah above Zilina for example) the Slovak rivers provided a useful contact with the Danube and rafters from Kralovany (at the Orava-Vah confluence) would work through to the Black Sea until the 1870s when the railways captured the long-distance traffic. Meanwhile the Bistrita, Mures, Olt and Tisa were among those used in the southeastern part of the Carpathian Basin where the timber industry has been seen as a civilising force in the remoter areas (Turnock 1991). A detailed history of the Lotru valley refers to the development of capitalist logging companies in the 1850 s and 1860 s through the acquisition of watermills and forest concessions from the local peasant community ('obst'). Timber was first rafted down the Lotru and Olt and some salt was carried from Raureni to the Danube at Turnu Magurele in this way. Local sawmilling increased in 1873 through the factory at Brezoi (near the Lotru-Olt confluence) and transport on the Lotru was improved by dams ('opusturi') as far upstream as Vidra - capable of releasing an extra boost of water to cope with shallow depth - although disputes arose with farmers if flooding occurred. By the 1890s there were over a thousand workers employed in the valley by Austrian capital during the peak season producing $100,000 \mathrm{cu}$.m of sawn timber. The industry brought settled life to villages like Voineasa where the companies had to provide some of the local services although the work was hard with virtually no proper medical assistance until a road through the Lotru valley established a tourist industry (Moga and Stanciu 2002).
With a few notable exceptions, long-distance railways reduced the transport problems for the timber companies to the local scale: moving logs to the sawmills that were built at strategic points on the network. Some rivers continued to be used, because although beechwood was too heavy to float there was little demand for this type of wood before 1918. Thus the Vaser was used to supply the Viseu de Sus factory after long distance rafting in the Tisa basin was stopped by the arrival of the railway in Sighet in 1872; also on the Sebes from Bistra and Oasa to the Petresti papermill after railways put an end to extensive use of the Mures. But narrow-gauge railways were widely adopted by the 1890 s. They could be used in valleys unsuitable for floating and were in any case superior because waste was reduced while equipment and workers could be transported as well as timber. And as long as there was a gentle down valley gradient, timber could move largely by gravity with locomotives of only modest power required (indeed some early railways worked by gravity with loaded trains controlled by brakesmen and with horses to return empty wagons). They proved to be quite adaptable with a minimum curvature of only $30 \mathrm{~m}$ and scope for horseshoe bends in tributary valleys to moderate gradient. Various gauges were used and although the Bosnian gauge of $76 \mathrm{cms}$ became the most widely used standardisation was long delayed and there was great variety within the range of $60 \mathrm{cms}$ and one meter, including several unique cases e.g. 630,790 and $980 \mathrm{~mm}$.

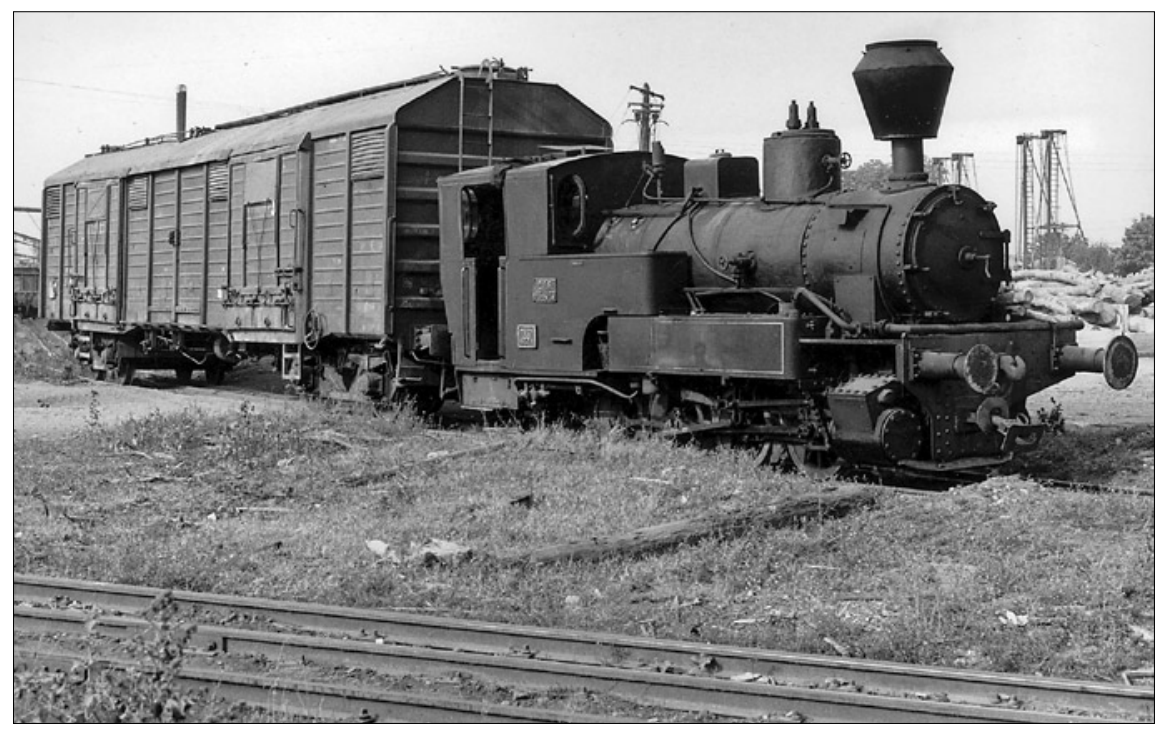

- Plate 2 Mixed gauge still survives at the Orastie woodyard so it possible for a narrow gauge locomotive to shunt a standard gauge wagon (1987) 


\section{pzc + GEOGRAPHICA PANNONICA}

The earliest railways used wooden rails (with a gauge as narrow of $60 \mathrm{cms}$ ) and animal traction, as at Finis near Beius in Transylvania. But those that became integrated with the developing main line system were laid with a stable permanent way using transverse sleepers that were suitable for locomotives. Some interchange areas had mixed gauge (Plate 2). A good many examples have been researched in the Eastern Carpathians of Romania. Following the arrival of the CFR (Romanian state railway) at Piatra Neamt in 1885 , forest railways were built at Tarcau in 1899 and Valea Cuejdiului after 1908. Further north in what was then Austrian territory the "Bukowiner Lokalbahn (to Vama and Moldovita in 1889; and Putna and Nisipitu in 1898) was the trigger for the Or thodox Church estate ('Religionsfonds') to expand logging and gradually to create a system under their own control which comprised $1,200 \mathrm{kms}$ of roads and $228 \mathrm{kms}$ of railways (by 1910) in the Falcau, Frasin, Gura Humorului, Moldovita, Nisipitul, Paltinoasa, Putna and Voronet areas. Some lines were isolated from public railways like the Gainesti system west of Falticeni, which nevertheless included the Malini inclined plane (1892) to connect two levels. The upper Bistrita was remarkable for the retention of rafting above $\mathrm{Pi}$ atra Neamt (Anania 1910) which gave rise to a number of isolated forest railway feeders at Borca in 1890 and Crucea in 1909 (and there is also a reference to use of inclines into the Bistricioara Valley until the system was destroyed by fire in 1906). And although steam locomotives (using the local wood fuel) became very widely used, the risk of fire at the Busteni papernmill led to a decision in 1899 to electrify their $70 \mathrm{~cm}$ system (built in 1882). This railway was also remarkable for the of use of $f u-$ niculars (including one nine kilometers in length) to reach the forests of the Ialomita and Retivoi valleys.

\section{Transylvania and Especially the Comandau System}

In Transylvania where the commercial impulses were stronger, several forest rail ways were triggered by the arrival of standard gauge railways such as the completion of the semicircular route in the eastern part of the province from Brasov to Miercurea Ciuc, Toplita, Reghin, Targu Mures and Turda in 1909 which set off a spate of construction from Subcetate, Toplita and Rastolita - one example being the Mures Valley Wood Production Company's railway which reached the upper Bistricioara valley from Toplita. Figure 2 - highlighting the Buzau, Covasna and Vrancea areas - shows the Sfantu Gheorghe-Targu Secuiesc branch of 1891 which provided the base for two lines built simultaneously to the upper Basca catchment around $\mathrm{Co}_{-}$

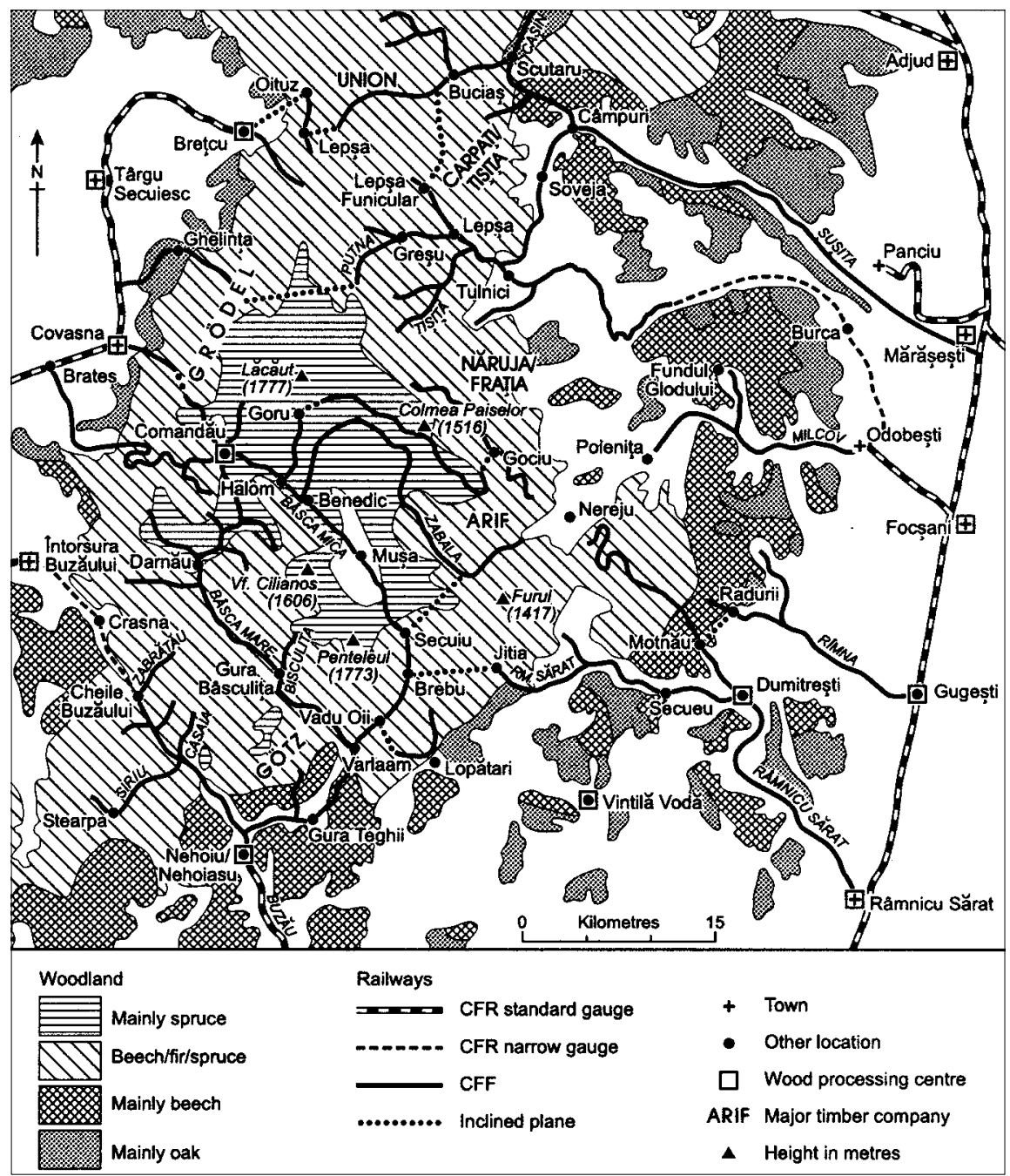

Figure 2 Forest railway networks in the Eastern Carpathians between the Trotus and Buzau valleys.

mandau at an altitude of over 1,000m: one from Brates which required a spiralling track to gain height and another from $\mathrm{Cov}^{-}$ asna which used an inclined plane at the head of Valea Zanelor ('The Valley of the Fairies'). Commercial development dated back to 1888 when a wooden railway for animal traction was built to Halom at the head of the Basca Mare valley from Gyula

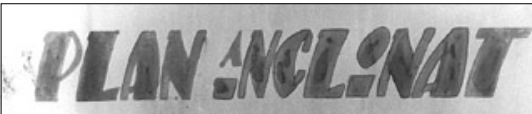

A EOST CONSTRTHT AN ANCZ 1886.

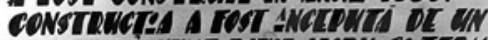

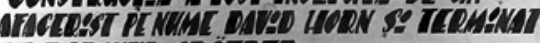
TI BADONTI CDOTDT.

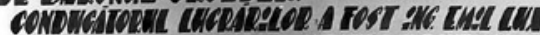

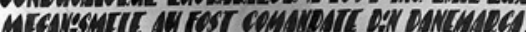
TIIMINTI TIINQCT:

\section{- TINGgNer $1202 \mathrm{~m}$}

- ICATITAMENT $1450 \mathrm{~mm}$

- cabrar Ø $28 \mathrm{~mm}$

-stiter ANCREcesine 1 bu

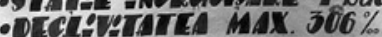

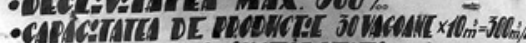
ACTPONADT ENSTICITE:

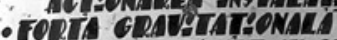
- SESTIEM DI IDANADE CH RADTE DEN ITMN

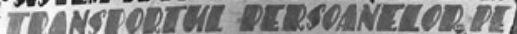

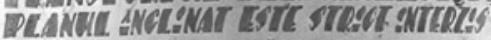

Plate 3 The notice board giving basic information about the Covasna inclined plane (1991). sawmill (named after the landlord Baron Gyula Zathureczky) where the Wolf engine still remains. Sawn timber was taken out by cart until the railway opened the prospect of a much larger scale of production. David Horn started the forest railway in Covasna at an altitude of $550 \mathrm{~m}$, but the interest was acquired Grödel's Transylvanian Forest Industry Company ('Societatea Ardeleana') and his engineer Emil Lux completed the inclined plane in 1892 with machinery supplied by T.Obach of Vienna (Plate 3). Danish-built the plane was $1,236 \mathrm{~m}$ long and took the railway from 686 to $1,013 \mathrm{~m}$. This was only one meter below the altitude of the terminus of Comandau, five kilometers north of Gyula where the sawmill was relocated and a forest community of about a thousand people developed; but the watershed lay at Cumpana $(1,075 \mathrm{~m})$ which meant a climb in both directions. The line is considered the first forest railway in Romania (present frontiers) using iron rails and steam locomotives (Lacriteanu et al. 1988) (Figure 3)

Grödel cut timber in the Basca Mare valley and then acquired land in the Basca Mica in 1904 (on the Romanian side of the border) which required a railway extension over the watershed at Halom. This new branch replaced the older line to Halom and 


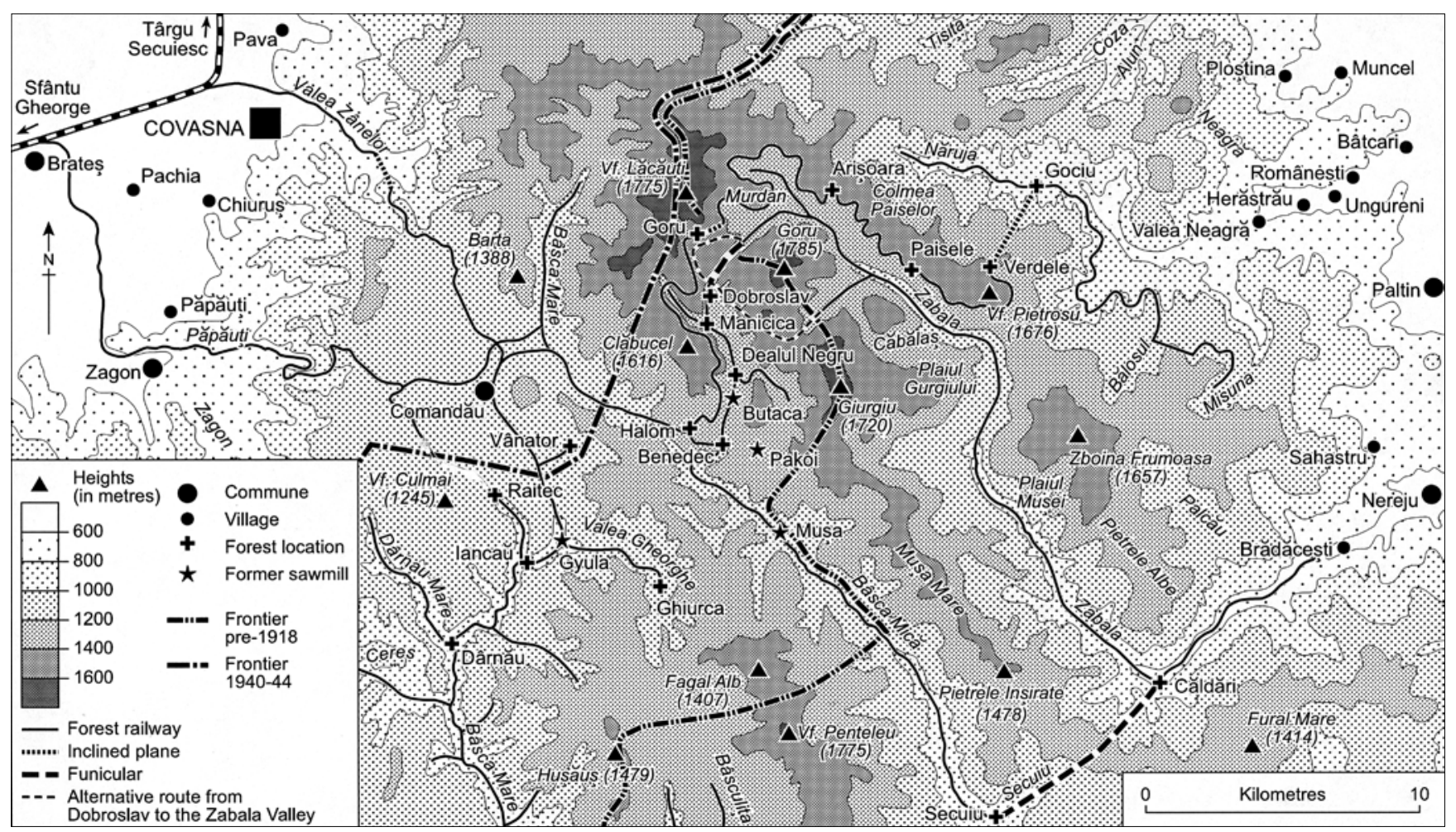

- Figure 3 Forest railways in the Covasna-Comandau area.

also extended it by means of the 'S' bend over the Basca Mare-Basca Mica watershed at $1,200 \mathrm{~m}$ and it was followed by an extension into Vrancea's Zabala Valley (referred to below). Meanwhile the CFR Nehoiasu branch (1909) enabled the rival Götz empire to push forest railways up the two Basca valleys from the lower end and eventually make contact with the Grödel system. The standard gauge railway was financed by the Marmarosch Blank bank which had been instrumental in attracting Götz to locate at Nehoiu in 1909 and acquire concessions the following year (Petrescu-Burloiu 1969). It was almost inevitable that the Götz and Grödel systems would connect, yet the two companies were competitors and relations were not always amicable. Maps produced by Mocanu (1970) suggests that Götz was connected with Covasna's second forest railway (from Brates) which eventually reached Comandau by a very different route and could have provided a northern outlet (perhaps for sawn timber) although it is not clear if this was used to any extent. At one point where the two systems crossed Grödel insisted on a bridge being built and this would have complicated the movement of any Götz timber in transit. Mocanu also shows a 'cut-off' route through Darnau which would have avoided Comandau but convincing evidence of this is lacking. Finally, the Tisita system was built during 1903-16 by the Austrian Count Mikes from the CFR's main line at Marasesti, but although it was easy to build along the Susita to Soveja, it was then necessary to cross the watershed to the Putna valley above Tulnici and then extend both ways along this valley: downstream towards Vidra and upstream to Lepsa and the narrow Tisita valleys which required some tunnelling. It was also notable for the use of a lubricated wooden trough the ('goanga') whereby horses could pull timber stems down short tributary valleys (Stefanescu-Morei 1957).

\section{The Inter-war Years}

The Gurghiu Forest Railway was built from Reghin to Lapusna in 1916 when the territory was still under Hungarian administration. But many more new lines opened after the war across the greatly-enlarged Romanian state: Casin (1920), Oituz (1929) - using a former German 'Feldbahn' - and Comanesti (1936) in Moldavia; Rastolita in Transylvania by 'Waldindustrie' in 1928; and Viseu de Sus in Maramures

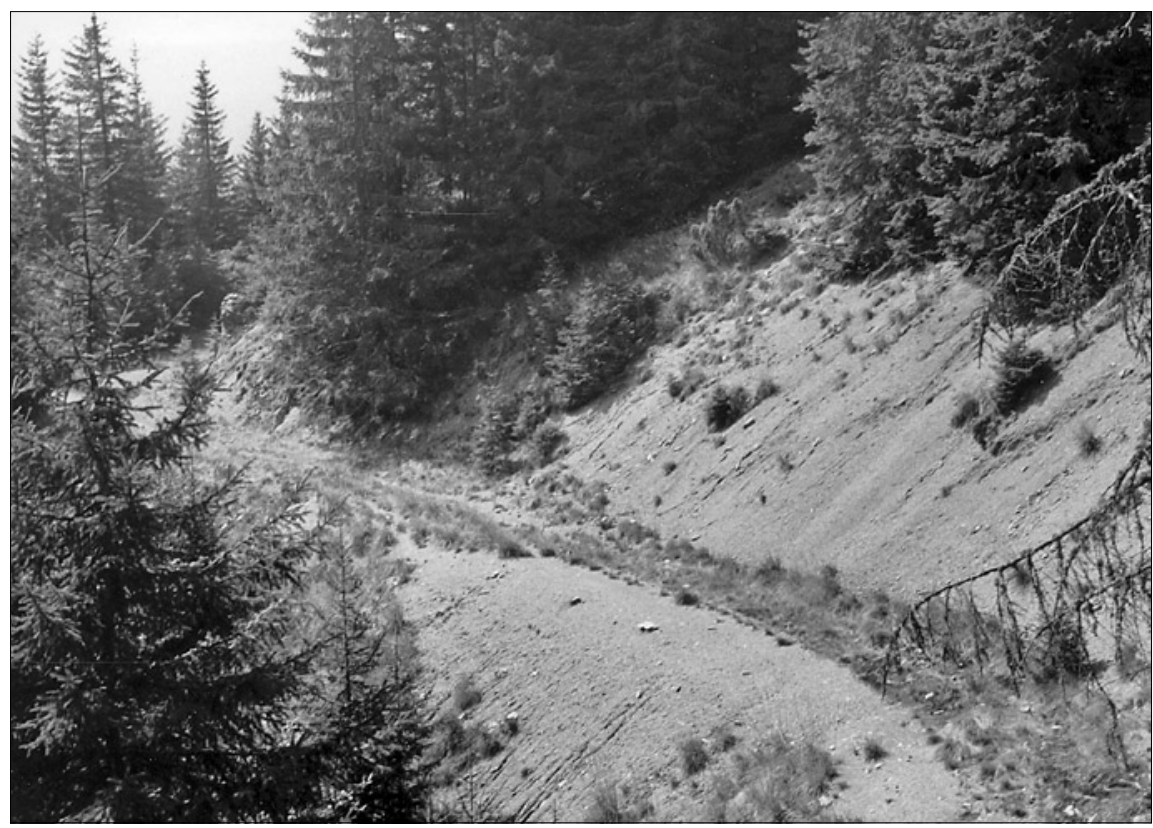

Plate 4 The trackbed of the Naruja branch clearly visible on the eastern slopes of the Zabala valley (1990)
(1932) where localised floating of timber on the Vasar finally came to an end (with the sluices at Botizu still in use at that time). The early 1920s also saw construction in Banat at Berzasca - on the Danube at the Iron Gates - and at Margina in the northeast. The logging companies in the Lotru valley built a feeder line along the Voinesita tributary valley to connect with the floating system that was still used in the main valley and another short railway from the Brezoi sawmill to the Pascoaiei valley connected with funiculars extending $15 \mathrm{kms}$ southwards through the Cheia valley to the Buila massif. There were also interesting developments in the Eastern Carpathian area already highlighted in 
the previous section. Although the connections in the Basca valleys had previously led to some timber trains crossing the frontier, the creation of Greater Romania increased the coordination across the main Carpathian watershed so that railways on the Transylvanian side could extend eastwards an access valuable timber on the upper surfaces on the Moldavian side, rather than have separate feeders into the mountains from mills on the Bacau-Focsani-Buzau main line.

This was a reflection of distance, but also of altitude because the valuable firspruce forests lay at $1,000-1,600 \mathrm{~m}$ - above the beech forests. So it was relatively easy to extend the Comandau system (already at $1,200 \mathrm{~m}$ at Halom) into the Zabala and Naruja basins to the east where further stands of resinous timber were immediately encountered. Such a development first occurred in c.1910 with inclined planes between Dobroslan at the head of the Basca Mica valley and the Zabala Valley. But a further link was constructed during 1922-7 to reach the Naruja Valley where the Fratia and Naruja companies gained concessions and started work in 1928. It would appear that loaded trains

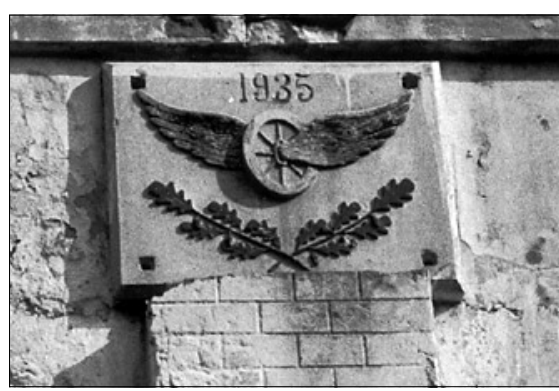

Plate 5 A plaque above the engine shed at Stalpeni recording the opening of the line by CAPS (1993)

ran on the level from the top of the Verdele inclines at $1,400 \mathrm{~m}$ almost to the ZabalaBasca Mare watershed where the short Goru incline was needed (Plate 4). From the watershed to Halom and Comandau a steady favourable gradient should have been possible (Roman 1989). It is thought that this line was closed in 1940 when territorial changes blocked the flow of timber to Comandau (which became Hungarian again for the duration of the war) but since the 1940 frontier lay further west of the old pre-1918 boundary the route from the Zabala Valley to Nehiou via the Basca Mica remained open. There is no evidence of any timber transport across the frontier at this time (unlike the situation before 1918). The inclines on the Naruja extension were of the same type as at Valea Zanelor: wagons were placed on cradles which kept them in a horizontal position. But the Zabala inclines were of the 'Bremsberg' type using conventional track and the wagons needed nets to hold the logs in place on the steep gradients. With loaded wagons coming out of the Zabala a

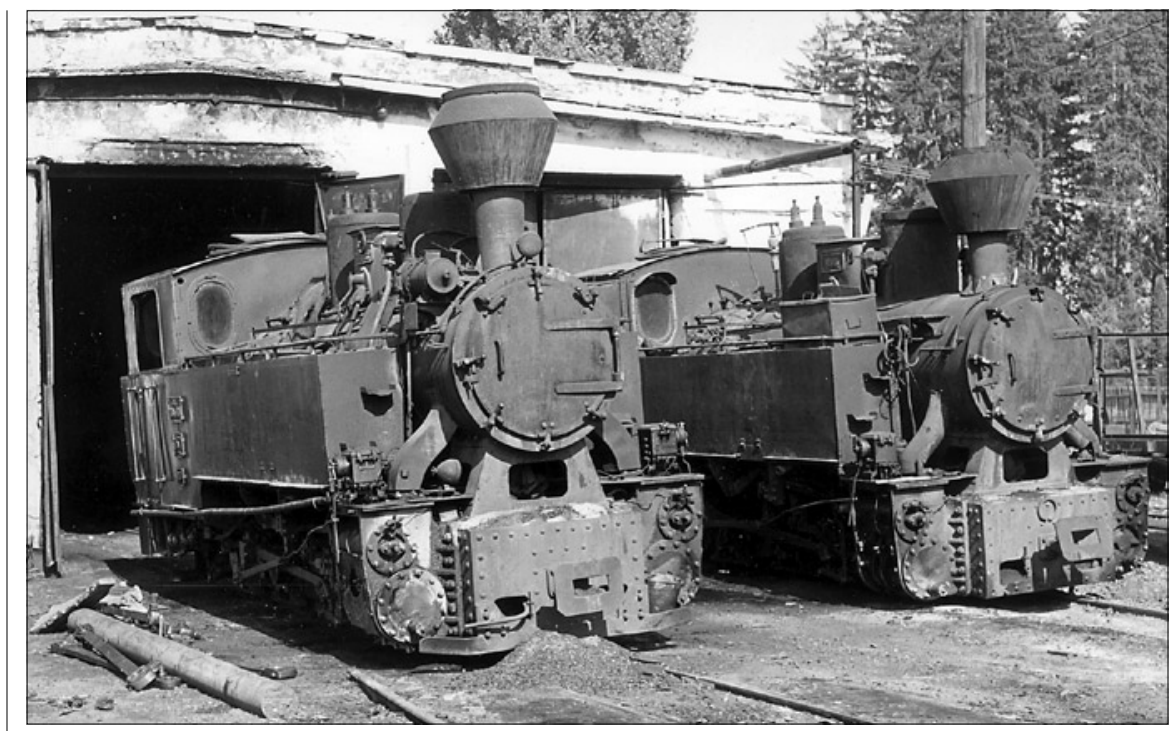

Plate 6 Two Resita locomotives at Tismana depot (1993)

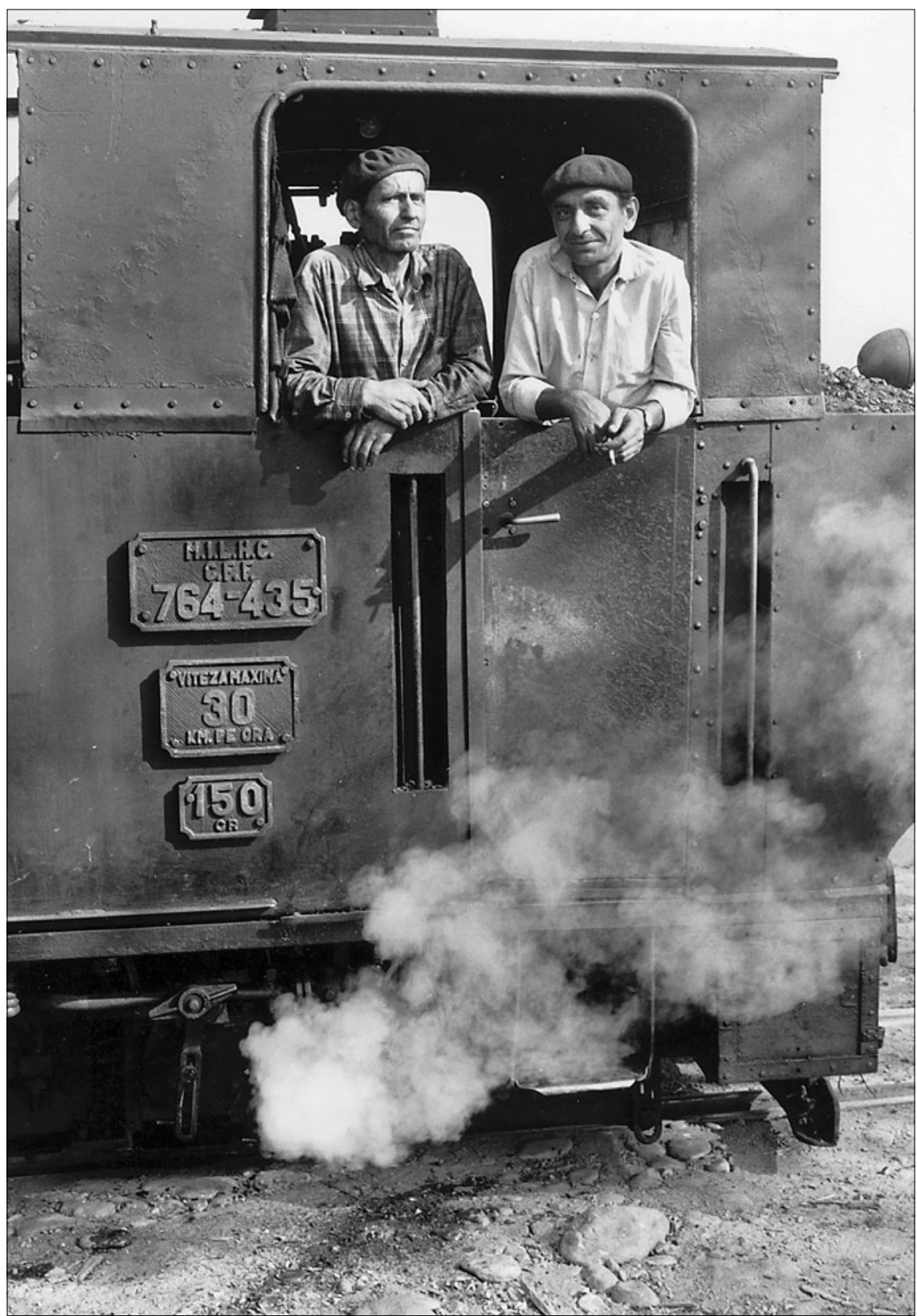

Plate 7 A Resita locomotive on the Tismana system (1975) with plates indicating the subordination of the CFF to the Ministry for the Wood, Paper and Cellulose Industry (MILHC), the locomotive type (76cm gauge and four driving axles - hence 764), locomotive number (435), maximum speed in $\mathrm{km} / \mathrm{h}$ and horse power. 


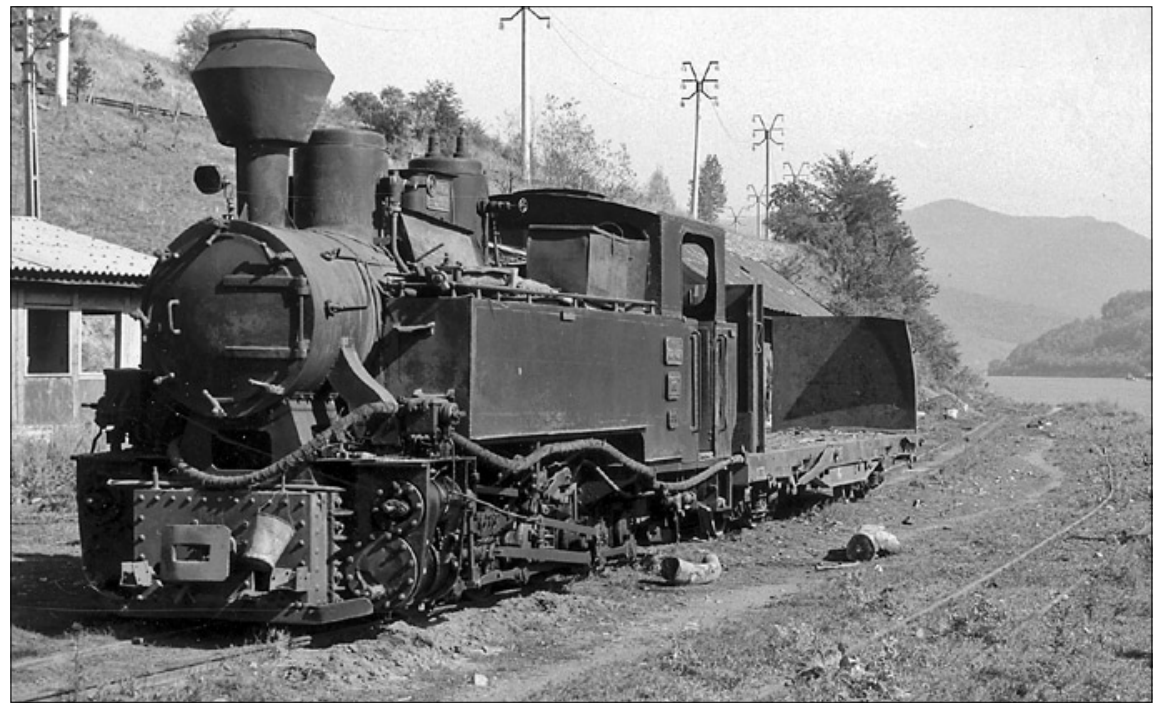

- Plate 8 The Reghin-built 'Resita' locomotive working on the Berzasca system (1992)

steam engine would have been needed at the summit, as was also the case at Goru and Verdele. By contrast the Valea Zanelor incline was self-acting because each descending loaded wagon could raise the ascending empty wagon with only a braking system required. Maps show that two alternative routes were provided into the Zabala valley, presumably to avoid the inclined plane but no oral evidence or other interpretation is available. What is clear is the remarkable extent of the Comandau forest network at its fullest extent: easily the largest in Romania and probably in the Carpathians.

Important changes occurred on the Tisita system. Because of the difficulty in crossing the Susita-Putna watershed between Soveja and Lepsa, the system was closed at the lower end while the Putna section operated in isolation with funicular links of up to $10 \mathrm{kms}$ with Colonia Zernea on the Ghelinta system near Bret$\mathrm{cu}$, Lepsa on the Oituz system (not be confused with Lepsa in Vrancea) and Scutaru on the Casin system. Available dates include 1932 for Lepsa - also the date for the forest railway to the Oituz sawmill - and 1936 for Scutaru. Indeed in the latter case there were also funicular links with Susi- ta tributaries - especially the Cremenet - which had originally been accessed by the Tisita railway through wooden skid- ways. Another complex network of narrow gauge railways developed in Banat south of Anina immediately before and after the First World War and wood distillation at Carsa in the Minis Valley was efficient in the context of a gravity flow of timber and the reduction of raw timber haulage over the watershed between Anina and Steierdorf which required a lengthy deviation through Bradet. However the cutting of much of Carsa's catchment brought about a switch in manufacturing to Resita by means of a new narrow-gauge railway from the Caras Valley to Secu to join the established timber transport canal system in the Barzava valley. Here timber had been cut since the 18th century to supply the iron furnaces at Resita by floating down Barzava or carting charcoal. But in the period 1900-14 the Barzava was harnessed for hydropower and a canal system for timber was installed at the same time with the use of a chute or 'jilip' to feed tim-

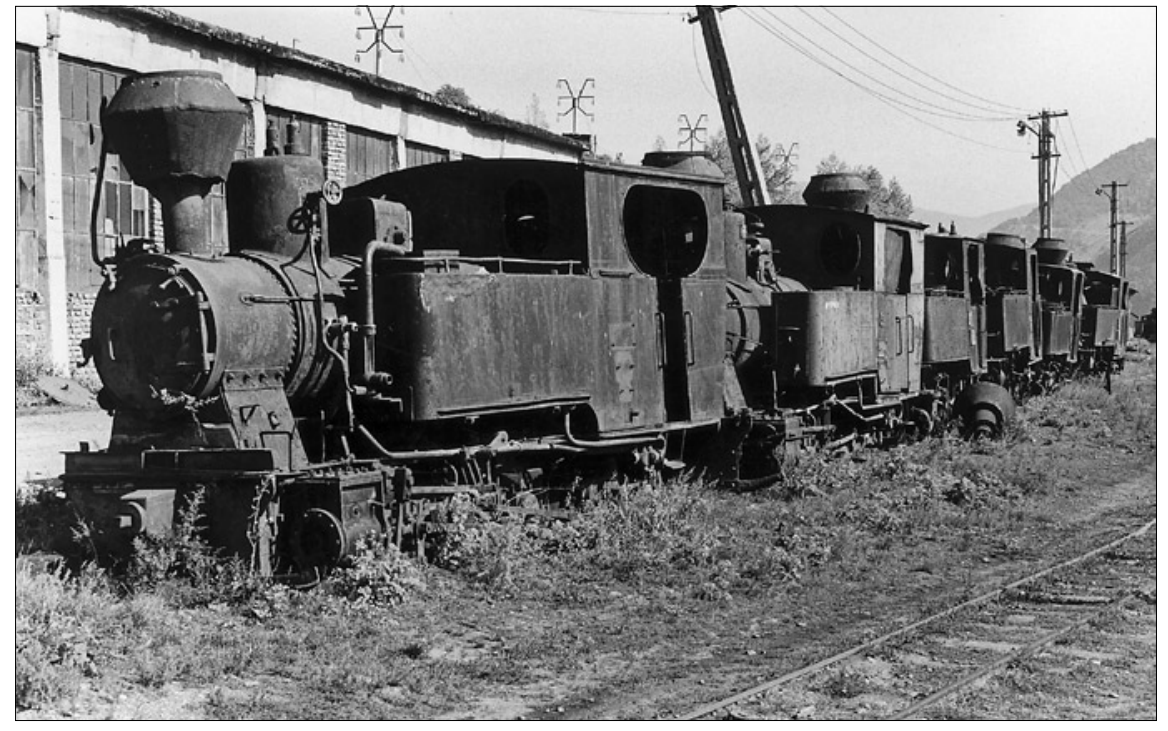

Plate 9 A row of six non-standard locomotives stored at Berzasca (1992)

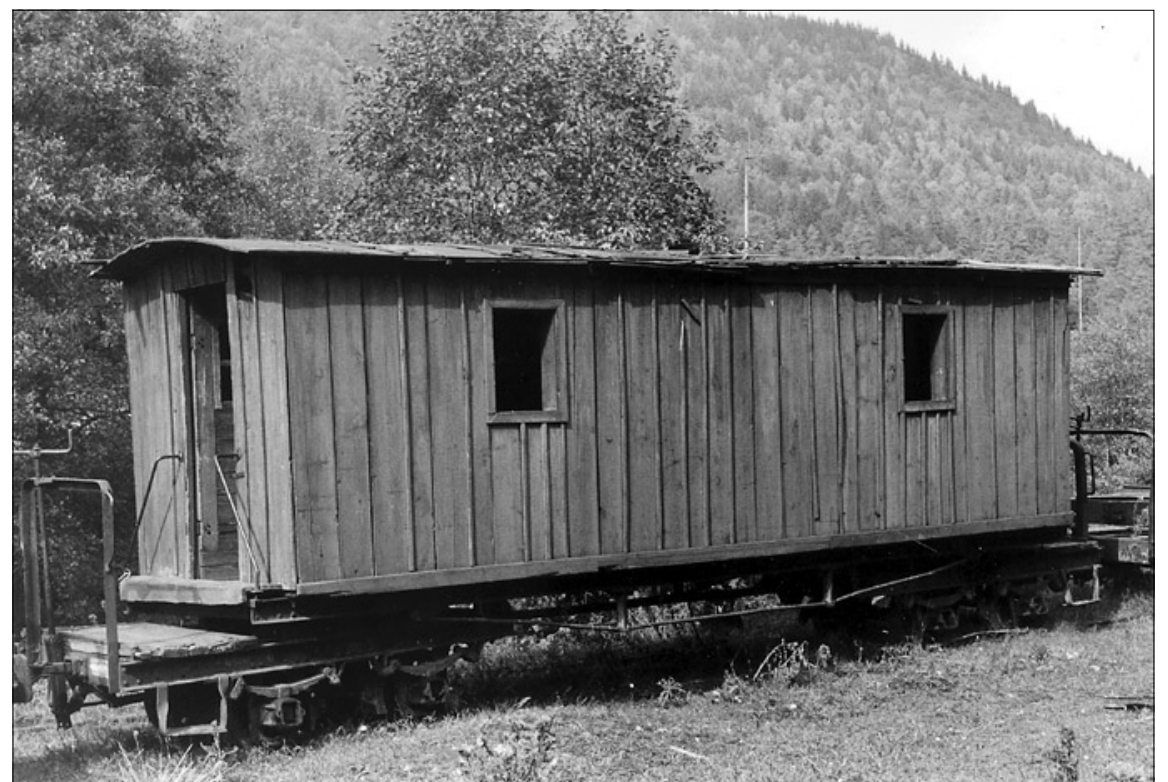

Plate 10 A 'sleeping car' on the Oituz system (1992) ber down the steep valley sides. Narrow gauge railways had developed around $\mathrm{Re}$ sita from the 1870s but primarily for minerals rather than timber.

State Intervention through CAPS In 1928 the state took an initiative to correct a situation where only $0.85 \mathrm{mln}$.ha of a total state forest estate of $1.89 \mathrm{mln}$.ha was exploited (or accessible). A 'Casa Autonoma a Padurilor Statului' (CAPS) sought more rational exploitation - and greater use of beechwood in particular - by railway building in areas like Stalpeni north of Pitesti in 1935 (Plate 5). In the same year another line was built through Valcea's Bistrita gorge to transport timber to the Arnota sawmill which had opened the previous year. The line was extended to the standard gauge railway at Babeni (south of Ramnicu Valcea) during the war whereupon the sawmill was relocated in 1953. CAPS also took over the Giurghiu Valley line from Reghin and the Leordina-Socolau line in Maramures - built as an 


\section{pzc + GEOGRAPHICA ANNONICA}

Austrian 'Feldbahn' to contain the Brussilov offensive during the First World War. More beechwood was used for furniture and cellulose, although much still went for charcoal and firewood - and $91.6 \%$ of the $2.24 \mathrm{mln} . c u$.m of timber produced in 1938 was still resinous compared with only 4.1 for beech and 4.3 for other species. CAPS also represented a belated compromise in the ideological struggle over the issue of private and state enterprise and it was this organisation that dealt with the Germans in 1939 to establish a joint company with 'Deutsche Forstung Holzwirtschaftsgesellschaft' which covered 34,000 ha in the Pipirig-Rasca-Targu Neamt area of the Eastern Carpathians (taken over by the USSR after the war as the basis of a new Soviet-Romanian joint company Sovromlemn). CAPS used the $76 \mathrm{~cm}$ gauge and their standard locomotive developed in 1929 was the forerunner of the type used countrywide after nationalisation. However in 1928 only $2,780 \mathrm{kms}$ out of a total of $4,350 \mathrm{kms}$ of forest railways used the $76 \mathrm{~cm}$ gauge (there were also $1,400 \mathrm{kms}$ at $600 \mathrm{~mm}$ and $110 \mathrm{kms}$ at one metre plus $60 \mathrm{kms}$ using the CFR standard gauge. Evidently there was some rationalisation by 1938 when the total network was down to 3,500kms (with 16 fixed funiculars) and presumably many $600 \mathrm{~mm}$ lines, using horse traction, had been eliminated.

Enterprise groupings in the timber industry (Chicos 1926) highlight five arbitrary statistical areas in the Eastern Carpathians: Gheorgheni-Miercurea Ciuc with 5,420 workers and $6,070 \mathrm{hp}$ of installed power; followed by for Pojorita-Vatra Dornei with 2,740 and 3,480 respectively; Covasna-Nehoiu with 2,610 and 3,800; Comanesti-Darmanesti with 2,530 and 4,630; and Targu Mures-Toplita with 2,090 and 3,020. Figures for $1931-5$ suggest that $18 \mathrm{mln}$ cu.m of timber was being exploited annually: $10 \mathrm{mln}$ for processing and $8 \mathrm{mln}$ for firewood. The commercial companies continued to operate side by side with small-scale industry in the hands of peasants working

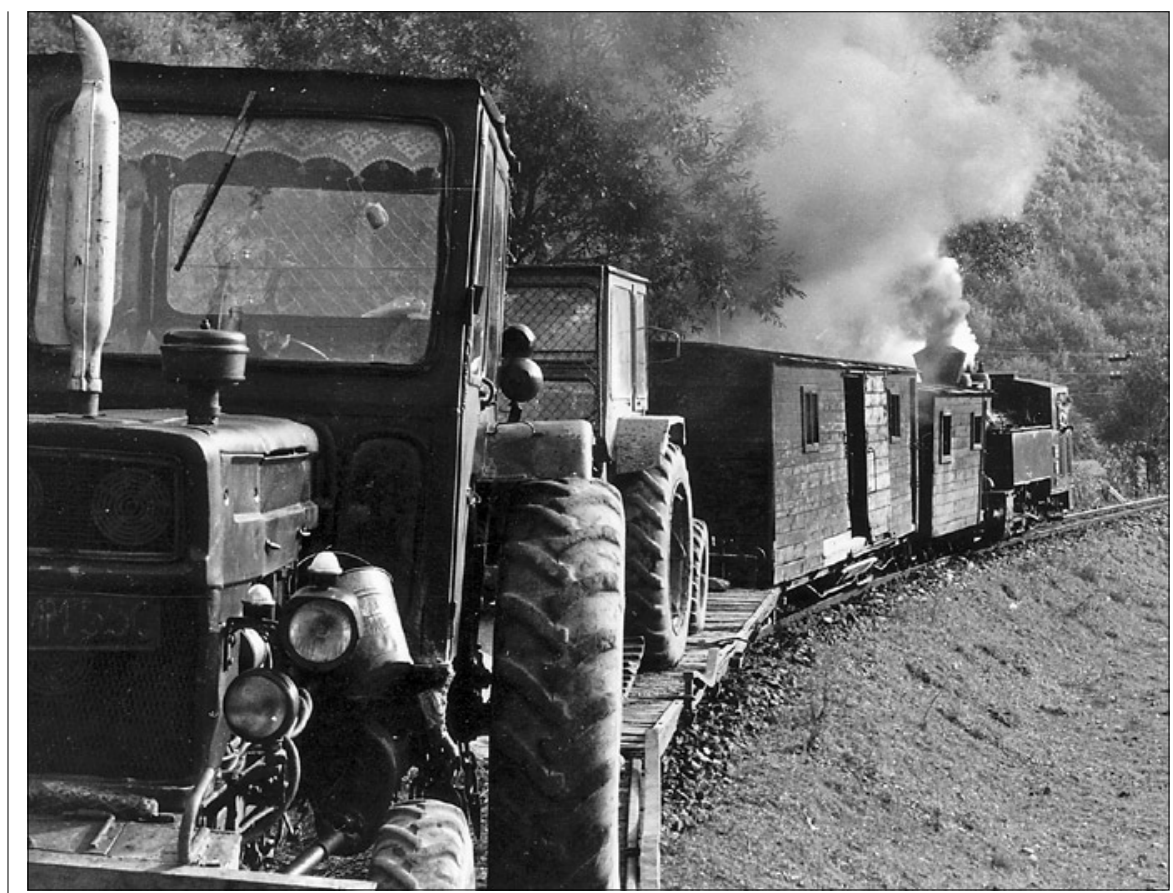

- Plate 11 Tractors being taken back to Viseu de Sus for repair (1981)

small private forests to serve a more local market. Indeed, allocation of woodlands to peasant families under the land reform strengthened this smaller scale of operation which typically gave rise to more small water-powered sawmills along Carpathian streams. In some cases the sawmill was one element in a complex of mills covering cornmilling and fulling as well. There were about 1,400 water-powered sawmills in Romania in 1940 and the industry was sufficiently buoyant for some entrepreneurs to graduate to larger premises as in the case of the Dinculescu mill built at Baia de Fier in 1930. Timber was floated a distance of some $20 \mathrm{kms}$ down the Galben and Oltet rivers in spring (when the water level was at its highest), while the finished planks ('scanduri') were taken on by cart to the nearest railhead at Targu Carbunesti. And a new private railway was built at Estelnic in Covasna (c.1933) as a collaborative venture to bring in timber to four separate Jewish-owned sawmills which then used lorries to take

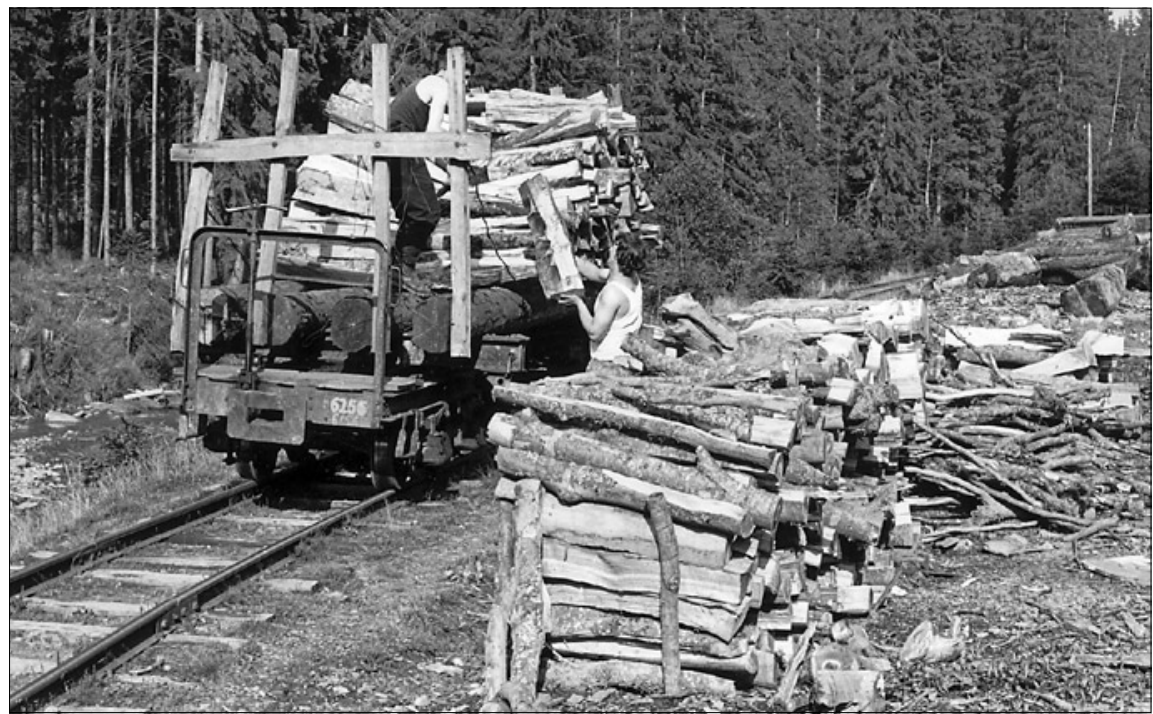

Plate 12 Hand-loading firewood by hand near Benedec on the Comandau system (1977) the finished planks to the standard gauge railhead at Bretcu. Finally it worth mentioning the development of tourism which increased the demand for proper passenger services on many forest railways, including the lower section of the Covasna system from 1932. The CAPS lines at Leordina and Reghin were included in the national railway timetable under the heading 'calea ferata particulara', while a converted tram was known to operate in Banat between the small resort of Poiana Marului and the CFR at Zavoi and King Carol II used a special railcar on the Gurghiu Valley system to reach his shooting lodge at Lapusna.

\section{The Communist Era}

Communism led to nationalisation in 1948 and a surge of planting which covered 600,000 ha to 1955 . However, annual harvesting at a rate of $5.0 \mathrm{cu} . \mathrm{m} / \mathrm{ha}$ was way in excess of annual growth averaging 3.8 (4.8 for spruce, 3.6 for beech and 2.9 for oak) so the forests became gradually younger and thinner. Organised across whole basins - 'unitati forestiere mari' (UFM) - 80\% were exploited by railways, roads or funiculars against $10 \%$ by water and animals ('atelaje') while another $10 \%$ remained inaccessible. Romania was obliged to deliver wood to the USSR as war reparations, following on from heavy wartime pressure on the forests for the benefit of the Axis. So it was necessary to open up new stands of timber and there was an unprecedented expansion of forest railways during the 1950s undertaken by the Romanian state and the joint Romanian-Soviet timber company Sovromlemn. It was considered more feasible to extend the railway network, despite challenging conditions in areas of unstable terrain. Romania did not have capacity for the production of motor vehicles at the time and since oil was also

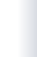




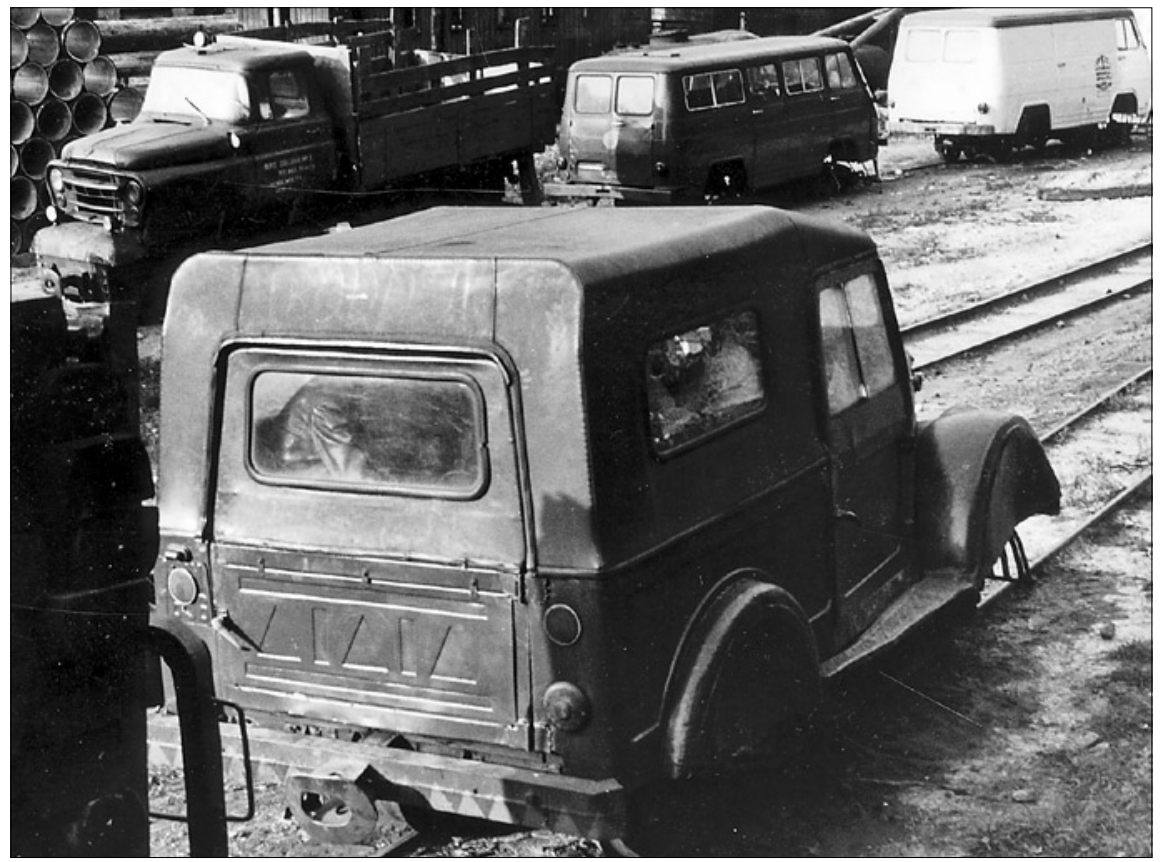

- Plate 13 A collection of 'draisinas' at Viseu de Sus (1981)

earmarked for reparations, a railway system operating largely on wood fuel was doubly appropriate. However roads increased their share of investment in new forest transport capacity from 10 to $26 \%$ during 1949-55 compared with 44 and $53 \%$ for rail while an animal, water and funicular systems declined (Mocanu 1970 p.26). With the CFF system unified under the Ministry fpr the Timber Paper \& Cellulose Industry, some $1,550 \mathrm{kms}$ of new railways lines were built between 1948 and 1960, making much use of local 'patriotic' labour which was easily mobilised under the terror tactics of the time. Among the new railway systems connecting with the CFR were: Teregova (1955) in Banat, Roznov (1952) in Moldavia and two systems in Transylvania: Orastie (1949, with additions to 1958) and Campu Cetati near Sovata (1954). In addition, the narrow gauge extension by the CFR from Intorsura Buzaului to the Crasna valley (1947) was transferred to the forestry sector in 1951. Use of the rivers was not yet finished for the new Cristisoru railway (1948) was linked with floating on the Bistrita, while Pipirig (1952) supplied the Targu Neamt sawmill which sent its produce away by road.

Many existing systems were restructured and extended. In 1952 an extensive network was opened at Falticeni which incorporated the formerly isolated Gainesti railway. And flood damage to the Lotru floating system led to its closure and an extension of the CFF from Brezoi to Voineasa during 1948-54, including new sections in some tributary valleys and a massive increase in the use of funiculars from the lone Cheia facility already mentioned to 21 by 1969: the value of these installations now being fully appreciated (Burghelea 1941). Another significant change arose in the southwest where the railway from Apa Neagra (near Baia de Arama) to Turnu
Severin opened in 1934 . However it was difficult to maintain because of landslides on the escarpment $150-300 \mathrm{~m}$ above the Danube between Colibasi and Malovatu; so an alternative route was provided to Targu Jiu in 1955 and the main centre of operations was then based at Tismana. But one of the most interesting extensions was made on the former CAPS Bistrita system where the steep gradient in the upper valley (climbing the extension of a railway that was already coping with gradients of 1 in 30. A funicular was built to the higher level in 1950 to reach Intre Rauri where a new six kilometer railway accessed virgin forest exploited by mobile funiculars powered by petrol engines. The line was worked by gravity (with horses to return the empty wagons) until a $65 \mathrm{hp}$ loco-tractor was introduced in 1953, followed by a small Resita locomotive in 1955 - which had to taken in by funicular in pieces and assembled at the site. The sys$170 \mathrm{~m}$ over just three kilometers) blocked tem worked until 1970 when the opening of a forest road allowed conversion to road transport (Bondoc 2002).

Meanwhile, there was much rationalisation in the Comandau-Nehoiu area e.g. by diverting Zabala timber to the new Caldari-Secuiu funicular, thereby reducing the distance to the Nehoiu sawmill, while timber from the Slanic valley above Lopatari was taken out over a new funicular to Vadu Oii and the Ramnic valley was linked through another funicular from Jitia to Brebu. In Vrancea the Motnau-Radurii funicular allowed part of the timber from the latter valley to be taken to the Ramna system (thereby dispensing with the CFF in the Ramnic valley below $\mathrm{Du}-$ mitresti) and thence to the Gugesti sawmill on the CFR main line south of Focsani; while new railways headed up the Milcov valley from Odobesti. Further north, the long rail haul from Oituz to Onesti was replaced by a roadside funicular to the Bretcu railhead in 1957 (which survived until 1975). Some new branches were built around Comandau like the two-kilometer Dealu Negru-Gurghiu line at the head of the Basca Mica and the Vanator branch of the same length just south of Comandau, the steepest on the system with a gradient of 1 in 14 : a locomotive would propel a few empty wagons to the end of the branch where they would be loaded and then allowed to run by gravity to join the rear of a train on the principalline. Meanwhile, transport into the Covasna depression was rationalised by the closure of the line to Brates. The total extent of the CFF was some $6,000 \mathrm{kms}$ in 1960 by which time virtually all plans had been achieved. The most significant shortfall lay on the system based on Babeni in the Olt valley where the original line to the Bistrita valley was to have been extended westwards into the Cerna, Oltet and Plopi valleys as well, although the Luncavat valley was the only extension actually achieved.

Some 4,000 new wagons were built by the Toplet factory near Orsova, while a new fleet of standard 0-8-0 tank locomo-

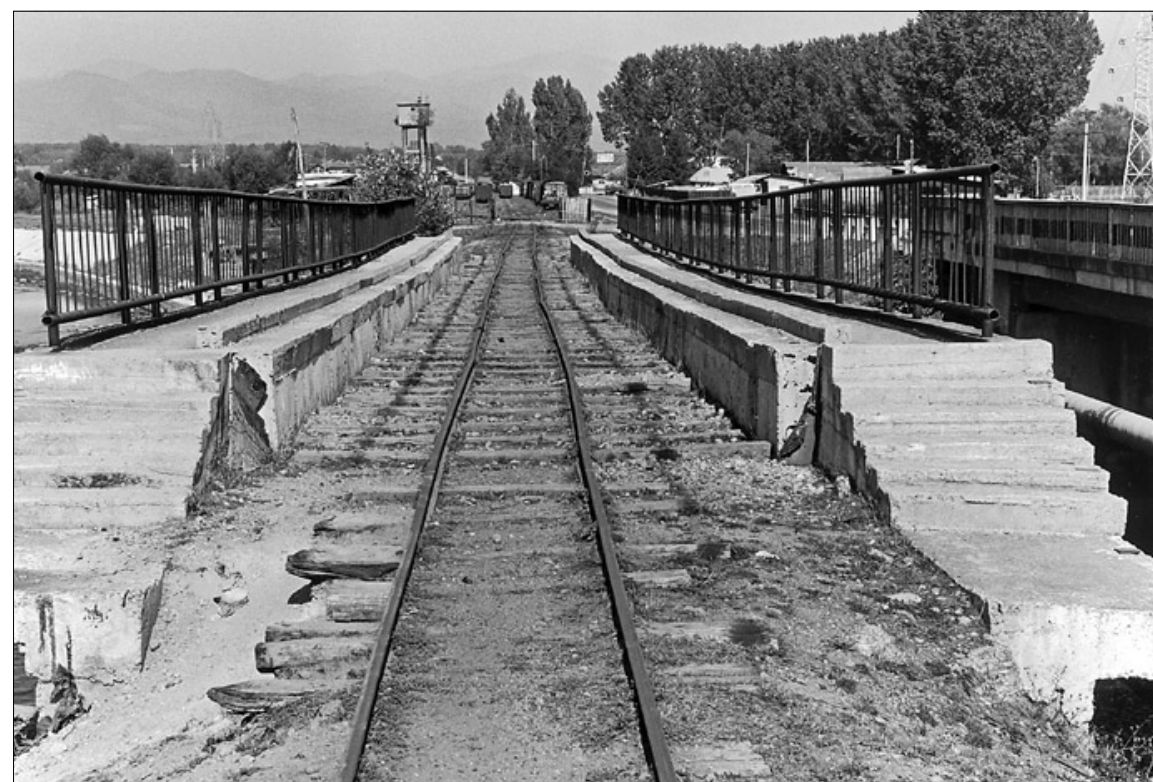

Plate 14 A concrete bridge at the approach to Tismana (1993) 
tives was built for the now-unified railway system 'Caile Ferate Forestiere' (CFF) by the Resita engineering works and the inherited fleet of locomotives (originating mainly in Austria, Germany and Hungary) was gradually replaced (Plates 6-7). However, a small number of the latter survived because although they were less powerful they were sometimes easier to handle on light, poorly-maintained track. Indeed no standard locomotive arrived at Berzasca until 1987! (Plates 8-9). There was also a building programme for passenger coaches (partly needed for public transport and for excursions) and mobile shops and dormitories, as well as covered wagons and tank wagons needed to carry the oil and fuel needed by the introduction and tractors and other machines built by the IRUM enterprise in Reghin (Plate 10). With mechanisation railway traffic increased since heavy equipment had to be transported to workshops for repair (Plate 11). Monday morning trains up-valley were therefore heavy with a full complement of workers as well as tractors. Even so the work remained labour-intensive with arduous hand-loading of wagons (Plate 12). From 1953 Reghin also acted as a central facility for major repairs but until this time each system maintained its own building capacities which meant that much equipment was built on the basis of local possibilities e.g. trolleys for gravity working and simple railcars (known as 'draisines' or 'drezinas') using the body shells of road vehicles which ultimately included ARO minibuses and DAC lorries (Plate 13). Many the orig-

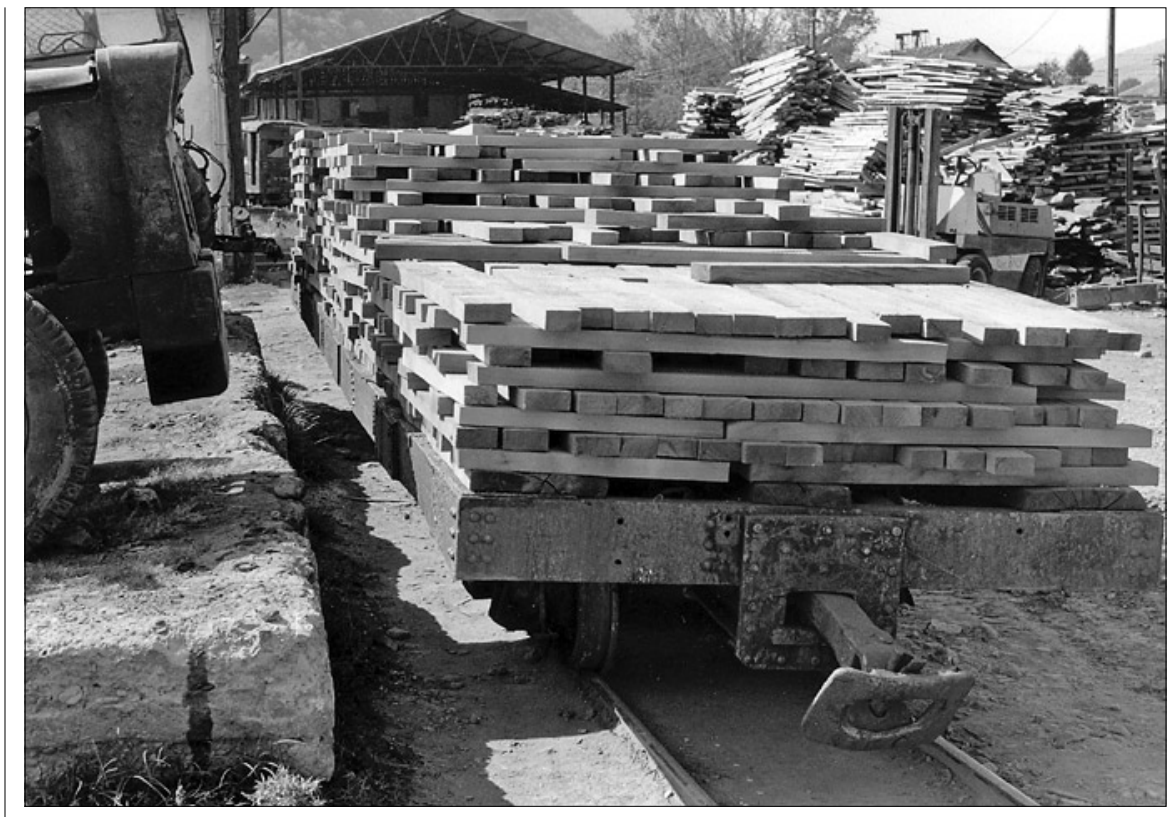

- Plate 15 Sawn timber at the Apa Neagra sawmill near Baia de Arama (1993)

inal wooden structures on the railways were rebuilt in concrete but trestle bridges occasionally survive (Plate 14).

\section{An Expanded Road Network}

From a high water mark in the late 1950s the CFF was overtaken by the road transport for which the necessary manufacturing capacity was now available and the total CFF network length was drastically cut down to $3,000 \mathrm{kms}$ in 1967 . Forest roads were emphasised by the Eighth RCP Congress in 1957: they had always had a role, but the end of the Romanian-Soviet joint companies and the plans for a na- tional motor vehicle industry opened the prospect of road transport as the principal mode. The high cost of railways was noted and the 'colonial' nature of funiculars was underlined on account of their low technical standard and lack of durability where wooden pylons were used. Much timber was wasted although the ideal of 'whole tree harvesting' has not yet been found achievable. But a major consideration was the introduction of new network of processing units - shown by square symbols in Figure 4 - involving the production of furniture, chipboard/hardboard, plywood and veneer. This allowed more bal-

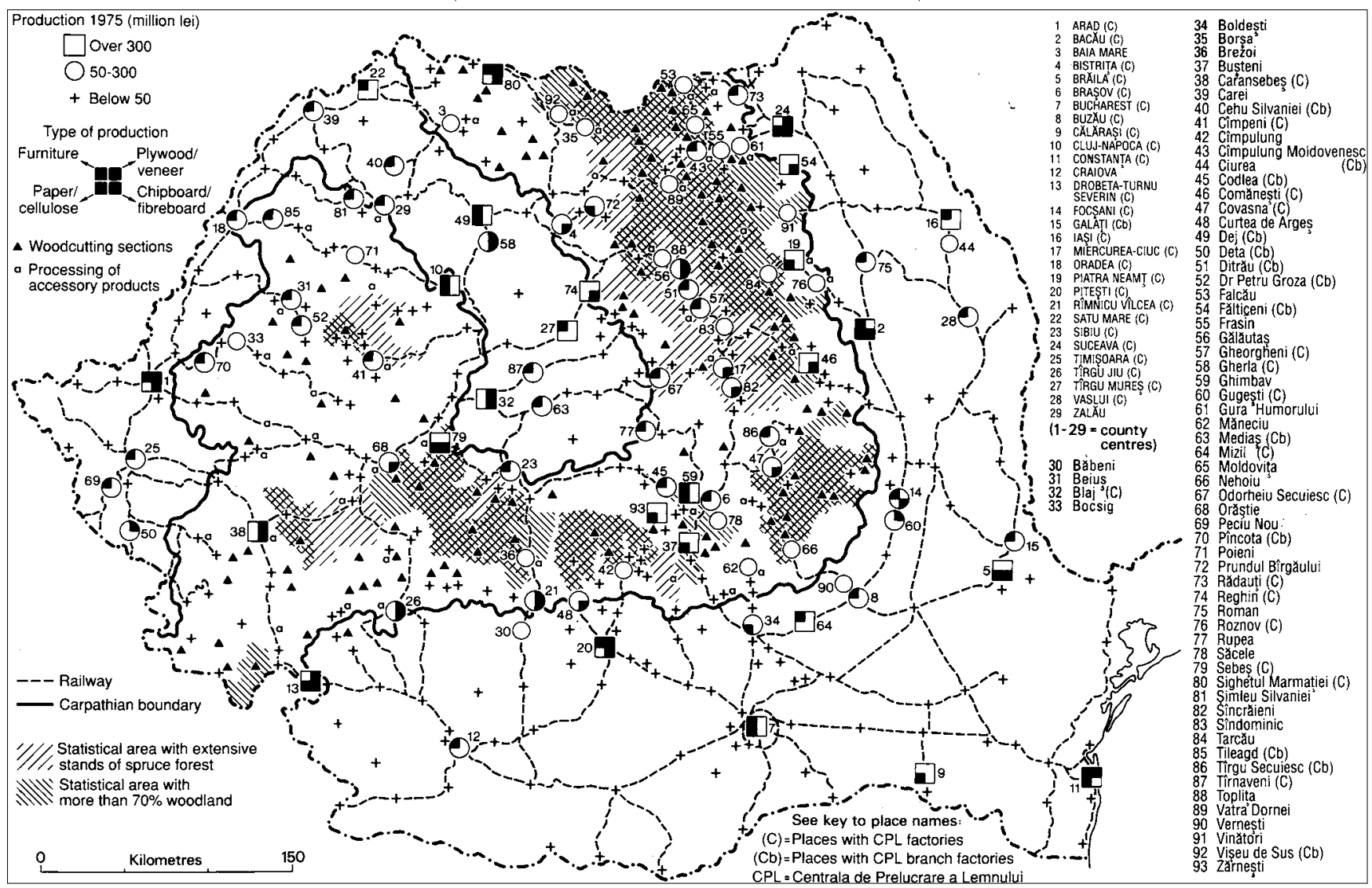

Figure 4 The Romanian wood processing industry in the 1970s 


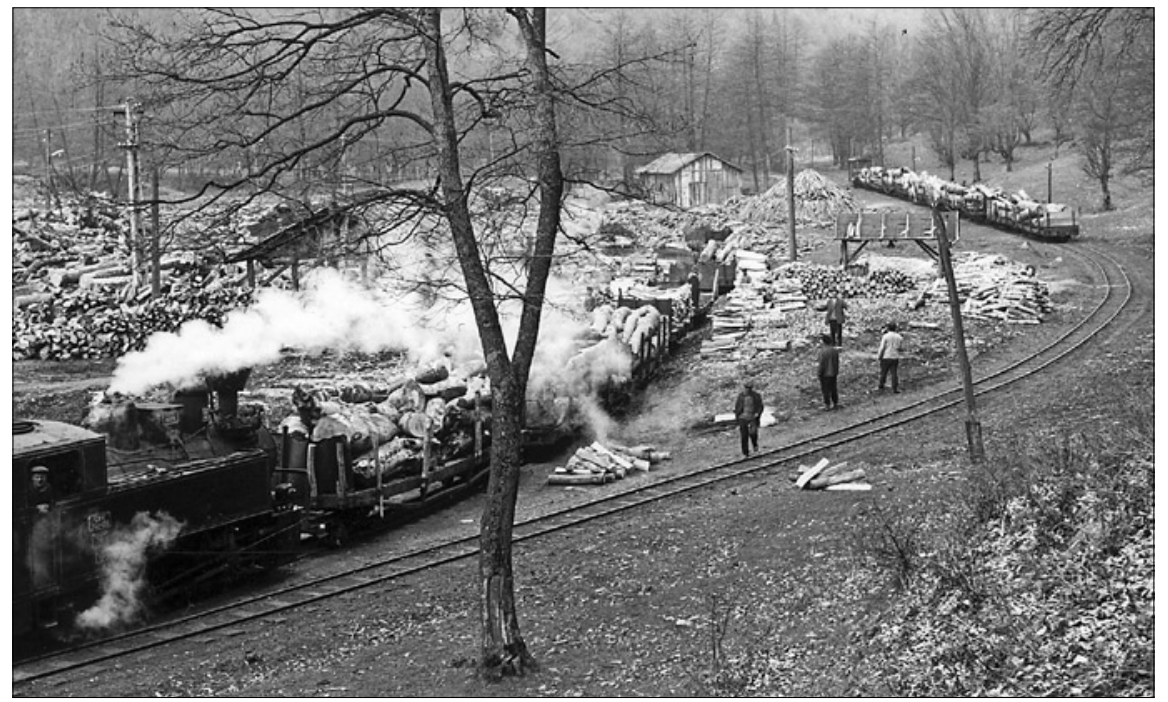

Plate 16 Wood being shunted into the charcoal yard at Riusor sawmill on the Stalpeni system (1983)

anced forest exploitation through greater use of beechwood compared with the selective felling of fir and spruce: the proportion of beechwood in the total timber harvest rose to $15.6 \%$ in 1955 and 26.3 in 1966 with the expansion of furniture and board production (Turnock 1990). These new complexes complemented the smaller specialist sawmills (many once privately owned) which continued to operate under the management of a branch of the state logging company - 'Intreprinderea Forestiera de Exploatare si Transport' (IFET) - or a cooperative supplying a specific need in a remote area (e.g. boxes for packing fruit): the latter sometimes used water power but most worked by electricity (Plates 15-16). Fortunately a number of the old mills were preserved in local museums or in the large technology museum ('Muzeul de Technice Populare') at Sibiu-Dumbrava.

Meanwhile, the new complex units required larger supply areas going beyond the capacity of individual railway systems and rationalisation swept away much of the CFF network, especially lines that were difficult to operate and maintain on account of severe adverse gradients and unstable Subcarpathian terrain. Thus the rail-road balance in new construction swung from 67:33 in 1948 and 83:17 in 1955 to 9:91 in 1959 (Mocanu 1970 p.27). It was intended that road density should increase from $6.2 \mathrm{~m} /$ ha in 1965 to 16.6 in 1990 (Ibid p.29) with 20.0 considered the optimum. The transition was accelerated by some instances of devastating flood damage e.g. the Nehoiu system in 1969 (Plate 17) when only the Siriu section survived as an isolated entity for some years and the adjacent Intorsura Buzaului system in 1973. Hydropower projects led to the closure of the Lotru system in 1969; also the lower sections at Rastolita and Teregova and the mountain sections at Tismana. However both these situations could result in partial retention of the CFF with the establishment of transfer points on the edge of the forest e.g. Anies, Rasca, Scutaru and Tazlau, so that road transport could supply the sawmills at Orastie, Falticeni, Onesti and Roznov respectively.

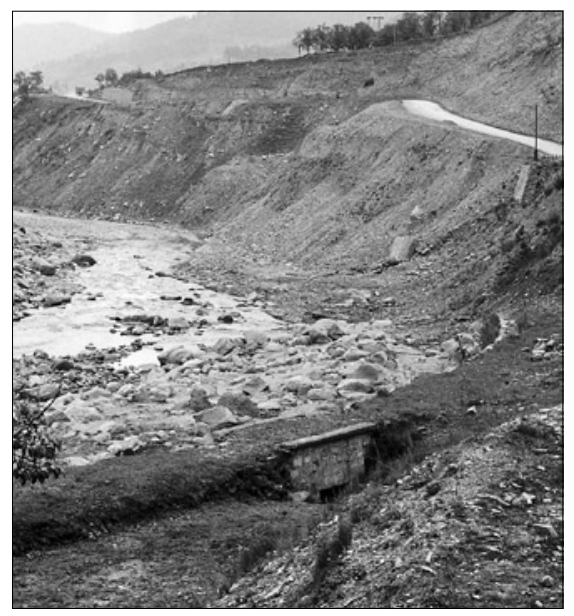

Plate 17 The Basca valley near Gura Teghii showing how the CFF trackbed was completely washed away in places (1976)

In the Eastern Carpathians this change had particular significance because Galati region (and subsequently Vrancea County) planned for the processing of its raw material within its own borders and therefore a comprehensive forest road programme was implemented to eliminate the funicular systems and supply a new manufactur- ing complex in Focsani (Stefanescu 1968) Forest railways in the Milcov, Ramna and Ramnicu Sarat valleys were already supplying local processors in Gugesti and Odobesti, but most Vrancea timber was being 'exported' for processing elsewhere as already noted. 'Institutul de Studii si Proiectari in Industria Lemnului' (ISPIL) proposed forest road building during 1962-70 to realise a potential annual output of 540,000cu.m for sawmilling, other industrial processes and firewood, with a 38:62 balance between resinous timber and beechwood. Although there had been 32,700 ha of planting in Vrancea during 1948-1969 (including degraded land), the age structure of the resinous timber was unsatisfactory as a result of selective felling (though some old trees remained in the more inaccessible parts of the Milcov and Naruja basins). Mocanu (1970 p.44) emphasised the purely temporary character of the local transport systems and the need for a permanent resolution of the accessibility problem for Vrancea's 31 production units. Development based on the CFF and its funicular systems was considered less efficient than a new unitary road system that would also be useful for mining (including oil) and tourism. Some existing railways could have fitted into the new concept but although thought was given to extending the networks based on Gugesti and Odobesti - with possibility of using the CFR Odobesti-Burca narrow-gauge line as a route to the upper Putna valley - the physical conditions were considered too difficult. So the 1962 plan proposed an extension of the forest road network from 98 to $533 \mathrm{kms}$ covering the Milcov, Naruja, Putna, Susita and Zabala valleys (Stan \& Pasoi-Barco 1966). Within a year of the opening of the Focsani processing complex in 1960 the Caldari-Secuiu funicular was closed. The Lepsa Funicular-Scutaru funicular closed at the same time, although the link from Gresu to Lepsa remained until 1972. Meanwhile local sawmills in Vrancea - e.g. at Gresu and Vidra were closed and relocated by the regional administration, although the Naruja factory (damaged by fire in 1958) was restarted in 1970 to produce doors, window

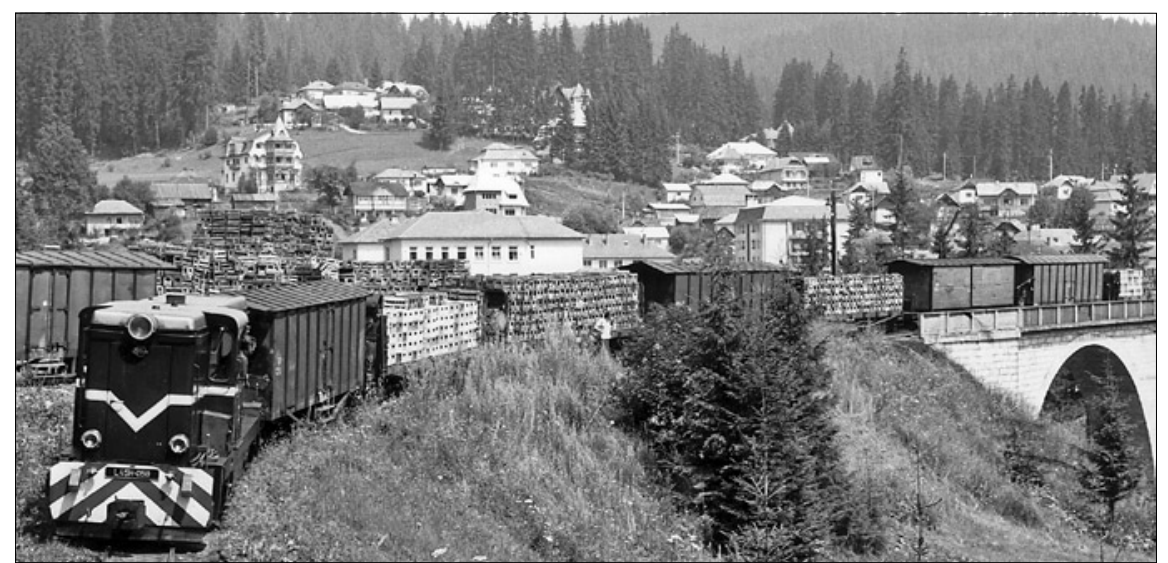

Plate 18 A traiload of mineral water leaves the Borsec bottling plant for Toplita (1977) 
frames and boxes as well as sawn timber (plus some processing of pine needles for pharmaceutical and fodder purposes from 1977).

CFF closures were certainly drastic during the late 1960s, although the ToplitaCorbu-Borsec railway was retained for the transport of mineral water (Plate 18). And when the Babeni-Bistrita line became redundant in 1970 it was transferred to the Govora Soda Factory and used exclusively for the transport of limestone from the Arnota quarry. However a further twist to the saga arose out of the oil price increases of the early 1970s by which time Romania had become a net oil importer. To economise on hydrocarbon fuels it was decided by the state logging industry ('Centrul Exploatatri Lemnului': CEL) that all the remaining forest railways should be retained. A number of new 'Resita' steam locomotives were built by the engineering enterprise UPS at Reghin: 12 were delivered during 1982-7. A number of diesel locomotives were also supplied although they were only considered economical for very heavy trains. Furthermore, some individual logging enterprises repaired flood damage (on the Vaser in 1982 and at Comanesti in 1985), while entirely new extensions were built on the Moldovita and Rasca systems as late as 1986-7 and IFET Caransebes had serious intentions about reopening railways at Crusovat and Zavoi. Consequently, around $1,000 \mathrm{kms}$ of the CFF still existed in 1989, spread across 21 systems (Reichel \& Hufnagel 1990) while narrow-gauge steam locomotives continued to shunt the Orastie woodyard (Plate 19). Under new accounting systems these railways have all since disappeared apart from Moldovita and Viseu de Sus where the CFF is considered viable long-term, even by the World Bank in the latter case (hence a loan to cope with renewed flood damage in recent years). But great interest has developed in the heritage value of the railways (Hofmeister 1986; Beier \& Hufnagel 1993) after much material was literally 'left to rot' in the communist era (Plate 20).

\section{Preservation}

There are now preserved forest railways in Slovakia where the Hronec-Cierny Balog section was reopened in 1993 (Chester 1995) while Poland'a Bieszczady railway which once extended some $40 \mathrm{kms}$ southeastwards from the main line at Lupkow is now operating over an isolated section around Cisna. In Romania there is now strong financial support from enthusiasts at Viseu de Sus <www.wassertalbahn. ch $\rangle\langle$ www.cffviseu.ro $\rangle$, but a purely preserved railway set-up has been achieved at Covasna after gradual run-down ever since Comandau's links with Nehoiu were destroyed through flood damage by 1974 when the limits were Darnau in the Basca

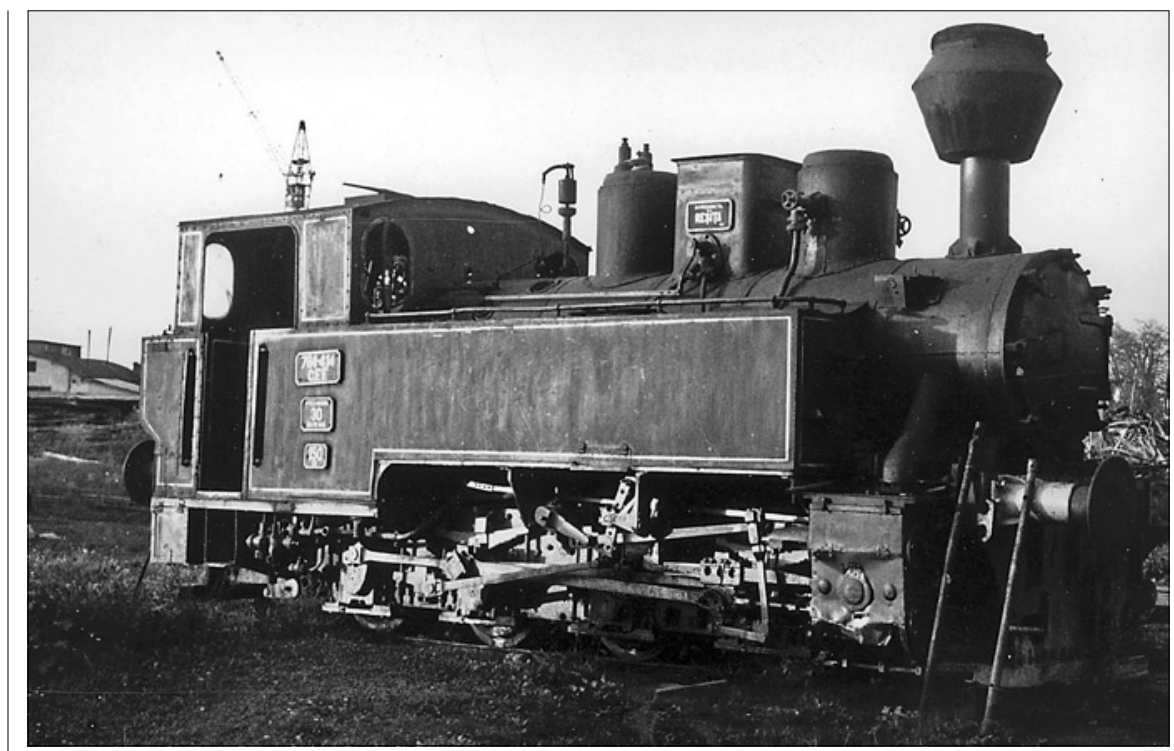

Plate 19 Twilight at the Orastie woodyard (1993)

Mare and Benedec in the Basca Mica. The Basca Mare branch closed in 1991 (it was reduced to the Gyula section by that time) while the line to the Basca Mica terminated at Halom after the Manicica extension closed in 1995. Major problems arose through the privatisation of logging because only the former state enterprise (IFET Brasov, now Brafor) continued to use the railway. Eventually, with annual felling in the area reduced drastically (18050,000 cu.m) to allow recovery from storm damage in 1995, the Comandau sawmill was forced to close in 1999 and railway operations ceased immediately. Before this the all-important inclined plane had been hit first by the storm damage and again in 1997 by a forest fire; although repairs were carried out on both occasions despite pressure to keep maintenance expenditure to a minimum.

Fortunately the installation has been safeguarded as public property and the Siclau Association has reopened the line starting with the lower section in 2002 <www. kisvasut.hu/comandau> (Hufnagel et al.

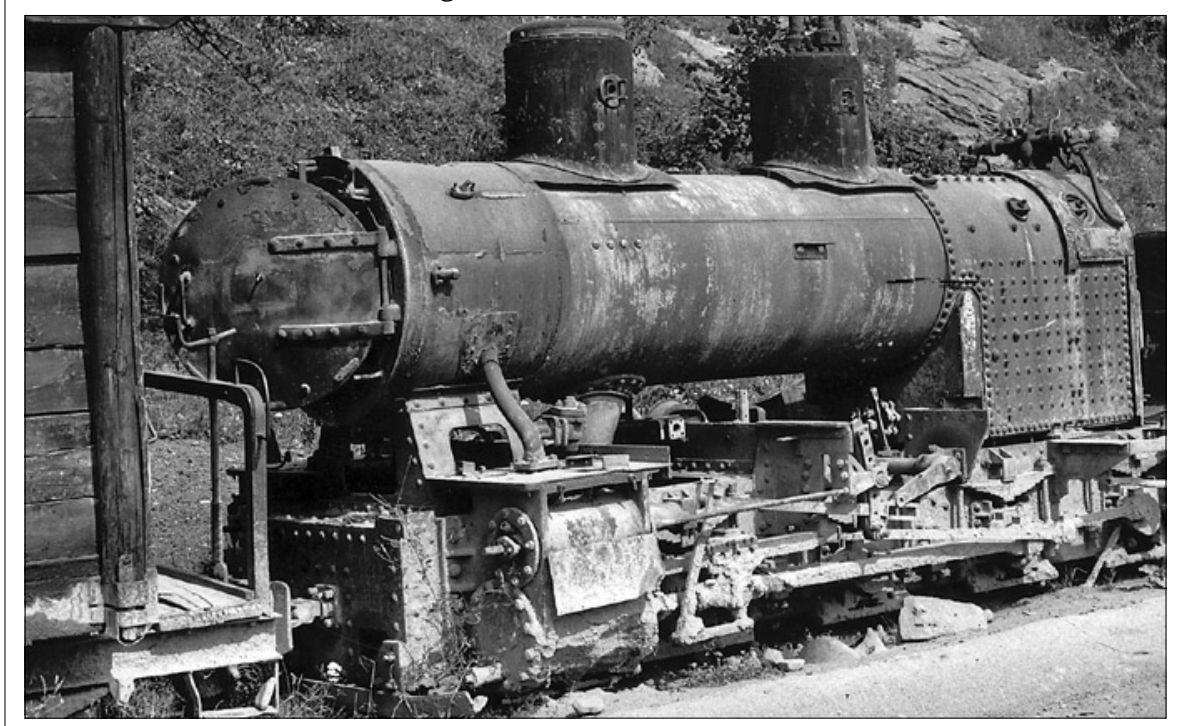

Plate 20 An abandoned locomotive and rolling stock on the Siriu branch of the Nehoiu which was operated as an independent unit for some years after the rest of the system was destroyed by floods (1977)
2002). There is a good stock of Resita standard locomotives (including two in the latest Reghin series) and a unique engine built by Krauss in Munich in 1916 (Plate 21). 'Draisinas' include one converted lorry and a converted Volga car. It is very important that the heritage should be preserved: in view of the challenging operating conditions whereby loaded timber trains had to work against the gradient from Benedec to Halom (where the line climbs from 1,130 to $1,200 \mathrm{~m}$ in just two kilometers) and on the approach to Comandau from Iancau and beyond; while trainloads of sawn timber (also some trunks and firewood) for Covasna had to go uphill from Comandau to the watershed at Cumpana: a stirring sight with Resita locomotives hauling 17 wagons up a maximum gradient of 1 in 33 ! But the incline is the "jewel in the crown': the sole surviving example of a gravity-operated self-acting incline system (Plate 22). Great care was needed to position loaded wagons correctly on the cradle at the top end (using horse power and subsequently a 'draisina') and there was also a tricky operation in the middle when the two cradles 


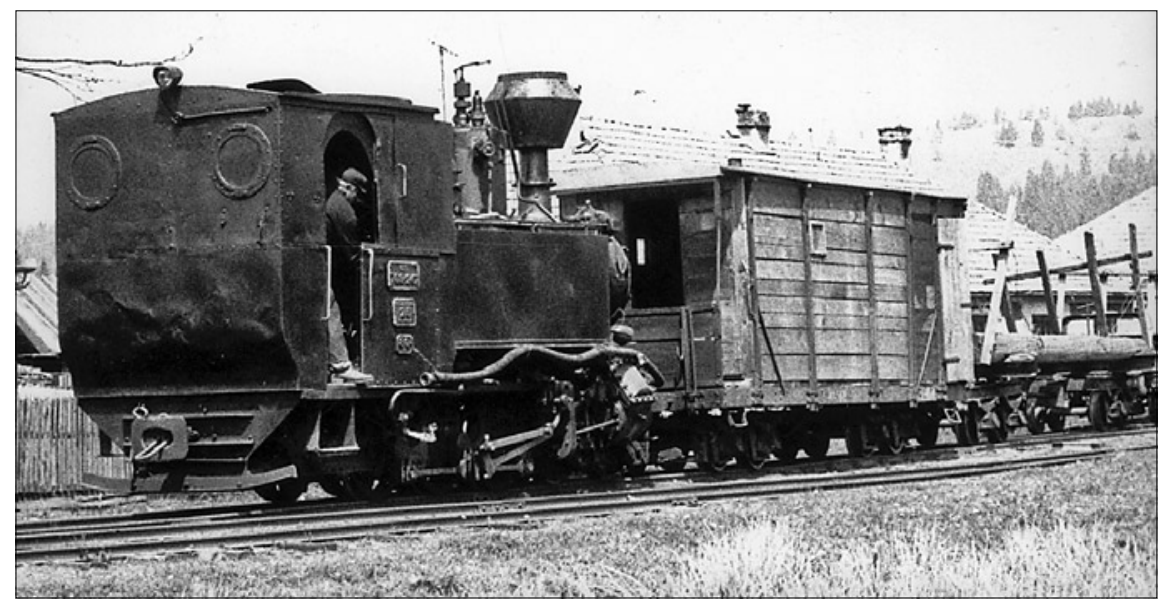

Plate 21 The Krauss locomotive shunting at Comandau (c.1980) Photo by K.Taylorson

crossed and weights were transferred to give extra weight to the ascending cradle, for although the lower half of the incline is steeper (climbing $167 \mathrm{~m}$ compared with $160 \mathrm{~m}$ for the top half) the weight of the cable is added to the lower cradle. The men also changed at the half-way point since man and horse formed a team at either end. Another curiosity was the stabling of the two horses at the bottom so the horse working at the top had to be taken up the incline on the first working each day (Titlow 2003).

\section{Conclusion}

This paper has discussed an industry that has attracted little academic interest over the years although - despite belated mechanisation - it involved very heavy work and primitive living conditions on the pioneer fringe. Even in the communist era, loggers would be away from home during each working week sleeping in dormitories with tiered beds in a most unpleasant atmosphere with smoke and smell; without light, running water or kitchen facilities; and all for below-average wages. No wonder that in many areas the job was abandoned whenever more congenial work became available and much of the activity was undertaken by migrant workers - particularly from Maramures - with the necessary physical capacity and capacity to adapt to work away from home. But the industry also has a place in the history of technology, not least through the ingenuity required to install transport systems for heavy loads where virtually none were already in existence. Today's forest roads provide the ultimate answer with access to virtually all woodland parcels and integration with the public road network at the same time. But such a situation has required heavy investment and the development of a motor industry. The other extreme involved the fullest use of the natu- ral river system with various refinements and accessories, but the intermediate 'railway age' had a particular interest through the great variations in the equipment and traction used, including inclines and funic-

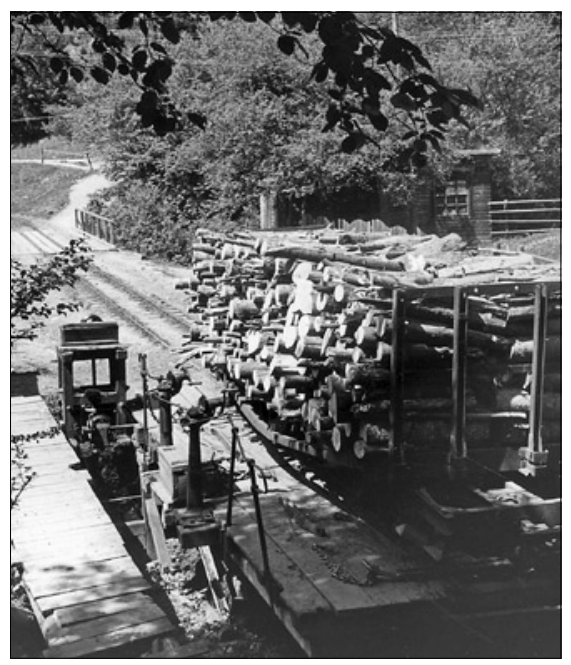

Plate 22 A wagonload of firewood at the bottom of the incline on the Covasna system (1994)

ulars to cope with the steepest gradients. It is good that the heritage value of these systems is being belatedly appreciated although the timber industry still attracts little public attention despite the crucial role of the forests for global conservation.

\section{Bibliography}

M. Anania 1900, Descrierea padurei Tarcau si plutaria pe Bistrita (Bucharest: Gutenberg).

R. Beier \& H. Hufnagel 1993, Wald und Dampf II: Bilder aud vergangen Tagen des CFF (Gablitz: Otto Novacek).

D.Bondoc 2002, Cotesti-Valcea: 45 secole de istorie - monografie (Ramnicu Valcea: Editura Offsetcolor)
D. Burghelea 1941, 'Funicularul ca mijloc de transport', Revista padurilor 53, 579-80.

K. Chester 1995, 'The Hronec forestry railway': K.Chester ed., East European narrow gauge (Clevedon: Channel View Publications) 73-81.

C. Chicos 1926, Groupement territorial de quelques industries en Roumanie (Bucharest: Curierul Judiciar).

F. Hofmeister 1986, Mit Dampf durch die Karpaten: Waldbahnen in Rumanien (Munchen: ECM-Buch/Bayerisches Eisenbahnmuseum).

H. Hufnagel et al. 2002, Calea ferata forestiera Covasna-Comandau (Budapest: Mester Nyomda)

S. Lacriteanu et al. 1988, The Covasna forestry railway and incline The Narrow Gauge 117, 15-9.

C.G. Mocanu 1970, Drumurile forestiere din Romania (Bucharest: Universitatea din Bucuresti Centrul de Multiplicare).

N.Moga \& G.Stanciu 2002, Voineasa: paradigma identitatii (Resita: Editura Timpul).

I. Petrescu-Burloiu 1969, 'Exploatarile forestiere si prelucrarea lemnului din muntii si dealurile Buzaului', Comunicare de Geografie 7, 205-15

R. Reichel \& H. Hufnagel 1990, Wald und Dampf: 1000kms auf den Waldbahnen Rumanians (Gablitz: Otto Novacek).

F. Roman 1989, Muntii nostri: Muntii Vrancei (Bucharest: Editura Stiintifica si Enciclopedica).

C. Stan \& A. Pasoi-Barco 1966, 'Dezvoltarea cailor de comunicatii si transporturi in Vrancea si zona subcarpatica dintre Susita si Rimna', Comunicari de Geografie 3, 203-10.

I. Stefanescu 1968, 'Studiul economico-geografic al padurilor din Vrancea', Comunicari de Geografie 5, 213-22.

C. Stefanescu-Morei 1957, 'Linii de alunecare: goange', Revista padurilor 71 , 260-7

J. Titlow 2003, ‘Transylvania's woodland wonder', Heritage Railway 45, 58-60.

D. Turnock 1990, 'Transport for Romania's Carpathian forests: improved accessibility through technological change', GeoJournal 22, 409-28.

D. Turnock 1991, 'Forest exploitation and its impact on transport and settlement in the Romanian Carpathians', Journal of Transport History 12, 37-60.

\section{Endnotes}

All by D. Turnock except where otherwise stated. 